\title{
RESSENYES
}

BALDWIN, John W.

The Language of Sex: Five voices Northen France around 1200

Chicago; London: University of Chicago Press, 1994. XXVIII, 331 p.

John Baldwin uses five distinct discourses -medical, theological, Andre the Chaplain for the Ovidian literature of the schools, the romances and the fabliaux to make a study of language and sexuality in northern France between 1185 and 1215. The fact that Baldwin uses five different discourses and restricts his study in this way is unusual as most studies of medieval sexuality have concentrated on one discourse or activity, but which has been placed in a geographically and chronologically extensive context. Unfortunately, like other studies of its kind the fact that the source material comes almost exclusively from men, with the exceptions of Marie de France and Marie d'Oignies, means that the work is subject to a masculine bias, and of course it must not be forgotten that even Marie d'Oignies' testimony reaches us through the voice of her confessor, Jacques de Vitry. While attempting to ignore any irony or humour in the texts, the author uses feminist terminology to give a historical interpretation of the texts by reducing them to a literal reading. He looks in turn at the different elements related to sexuality, such as sexual desire, the body, the physiological parameters and so on, sees how these are reflected and dealt with in the different discourses and evaluates the consequences these have for the construction of gender. In other words, he investigates medieval sexuality in terms of both gender and eroticism.

The period Baldwin examines was a time when women enjoyed sexual equality in a generally otherwise male dominated society; this was because of the still widely accepted Galenic two-sperm theory. Aristotle's theories, which had far reaching effects for women were later to change this. However, it was also the time when the sexual parameters for both clergy and laymen alike were being formulated. The ecclesiastics were intent on laying down the rules related to sexual behaviour (chastity, marriage, sexual intercourse) and on bringing them under their jurisdiction. In many ways they were very succesful and the five discourses reveal how the different sectors of the public to which they were directed agreed, disagreed or simply ignored them.

Baldwin argues that the upsurge of heterodoxy in France in the twelfth century with the revival of Manichean dualism, which condemned as evil sexual activity, propagation and marriage, left 
the theologians no alternative but to reconsider the question of human sexuality. They proceeded to lay down both the physical and social parameters of sexuality, that is, deciding what was socially and physically acceptable. But the church was also concerned with bringing marriage under its complete jurisdiction and with convincing the laity that this was right: Pope Innocent the Third's final victory in the ruling on Philip Augustus' and Queen Ingeborg's marriage facilitated the spread of the church's influence from the ruling classes down through to the rest of society. The author shows how biblical sources were used as arguments and he follows the members of Pierre the Chanter's school working back in an attempt to trace their source materials. By doing so he demonstrates how Augustine's views were inherited by the Chanter and his disciples and how they were vital in forming the theological tradition. Later on new views brought in by the Latin translations of Aristotle's works on natural science and metaphysics and which were so influential in forming later scholastic theology and philosophy, gradually gained ground and were to flourish in the later Middle Ages. Baldwin suggests that this means that Pierre the Chanter and his school of thought were really the last true disciples of the Augustine tradition.

Each discourse bears witness to a particular tradition within twelfth century France, but Baldwin's interest also lies in identifying their immediate audiences. The audiences of the particular discourses were, according to Baldwin, also reflected in the language used: by using common expressions and language the romances, which were originally intended for the aristocratic courts, were adapted for the common audiences. However, discourse is not necessarily a mirror image of society, but may itself act upon that very same sociery by affecting social behaviour. Baldwin suggests that the roman- ces, for example, proposed behaviour patterns and ideals which were eventually adopted by the aristocratic public to which they were addressed, while the fabliaux gave identity to the bourgeosie in the towns. In this way the different discourses were positively active in shaping society.

In addition, Baldwin asserts that by looking at more than one discourse we are more likely to form a truer picture of social reality than if we take each discourse individually. In other words, each discourse will represent an extreme, but when they are compared and contrasted with each other we can see how they overlap with each other and a general overall view of society is obtained. In other words, society is not entirely made up of sharply defined groups, but is conditioned by overlapping multiple discourses and for this reason it is important to look at the various differing discourses of the period in question if we want to get a truer picture. The author shows, for example, how two seemingly different discourses, the theological and Andre the Chaplain come surprinsingly dose in concurring with each other on the subject in question.

Each discourse is discussed in detail, leaving the reader in no doubt as to what it consists of and making it unnecessary to refer to the original itself if one does not wish to, although there are extensive notes on the texts at the end of the book. Each discourse is studied in conjunction with its *discursive tradition* and in this way Baldwin is able to demonstrate the contemporary structures and what the audiences of the day expected from each discourse. For example, he traces Pierre the Chanter back to Pierre the Lombard and Augustine, he shows how Jean Renart relates to the Tristan and Iseut legend and how Andre the Chaplain connects to the Ovidian tradition and so on.

In chapter two, which deals with the participants in the sexual act, Baldwin 
shows, for example, how Pierre the Chanter, drawing extensively from the scriptures, played and important role in the revival of homophobia. This was, in fact, the only position on which the other four discourses agreed unconditionally and whereas hermaphrodites were not to be blamed for their condition as it was their natural state, homosexuals were condemned. Other sexual acts which were not designed for procreation were also deemed sinful and the theologians even drew up a scale of "sinfulness" in which they classified in according to its seriousness and recommended appropriate punishments. Wirhin the physiological parameters relating to sexual activity there was also great debate about the age of men and women involved in sexual activity - how age affects performance, the ideal age for sexual activity and how one's "humours" affect sexual prowess.

John Baldwin also dedicates a section of the book to the social parameters, tracing the attitudes reflected in the different discourses back to their original traditions; for example, Andre the Chaplain again reflects Ovid, while at the same time drawing on other traditions as well. Social categories were drawn up and the author shows how these reflected the interests of the dominant groups within society: courtly love was for the aristrocrat, whereas the peasants were thought to be too tired for love of this sort after a hard day in the fields - theirs was of a more bestial nature! On the other hand, a peasant woman was considered fair game for rape as far as an aristocrat was concerned. In contrast to the romances the fabliaux reflected a richly diversified social scene. Baldwin concludes, therefore, that social disparity dominated both discourses and the characters remain aware of the social barricrs.

As sexuality was, for the theologians, related to the question of "concupiscentian they also considered the pathology of desire. Baldwin gives fascinating evidence of how while Andre the Chaplain distorted medical facts stating that intercourse weakens the body, causes insomnia and shortens life, the medical treatises sometimes recommended therapeutic coitus, such as frequent intercourse with many partners to relieve certain disorders. This was, of course, highly questionable to the theologians, who preferred to acast out satan by satanic meansn, using dubious therapies such as locking a cleric in a cell with his lover until they had tired each other out!

The discussion amongst the theologians in Pierre the Chanter's times about both the reduction of celibacy on the one hand and an attempt to create an absolutely clear division between the laity and the clergy in sexual matters on the other, is dealt with in chapter three. This was somerhing which had been overshadowed by Abelard's own experience and which was countered by the scholastic tradition of the clerical lover, the latter so often reflected in the bawdy fabliaux. However, the Lateran council in 1215 strengthened the requirements for chastity fully and made the religious calling a possibility for larger sections of the population. Here Baldwin reminds the reader that it was women like Marie d'Oignies, who, through their lifestyle and dress became what he calls aliving sermons" for the ecclesiastics. He shows how in contrast to the theologians the fabliaux uchallenged this feigned modesty" and therefore, at the same time aAugustine's shames, by exposing the male and female body to view.

Baldwin notes with interest how little attention was paid to the end result of an activity which generated so much interest. The church justified sexual activity as a means to and end and was therefore interested in fecundity, the sinfulness of contraception and fertility problems. This contrasts sharply with the almost total lack of interest in children displayed by the authors of the fabliaux and the 
romances, the one notable exception being the lais of Marie de France and it is suggested that this is because she is a woman.

The Language of Sex is an extremely interesting, very readable book. It is well written and full of fascinating informa-

\section{BROOKE, Christopher}

The Medieval Idea of Marriage

Oxford: Oxford University Press, 1989

Onze assajos, alguns d'ells publicats amb anterioritat, configuren aquest llibre de Christopher Brooke, professor d'història eclesiàstica a la Universitat de Cambridge. L'obra s'introdueix en l'anàlisi del matrimoni, en l'Europa Occidental, en el període comprès entre els anys 1000-1500, i se centra principalment en els segles XII i XIII. Brooke, un dels pioners en l'estudi del matrimoni, per penetrar en el seu objecte de recerca aplica metodologia d'història social, politica, religiosa i legal, també recorre a d'altres disciplines com la literatura, I'art, l'antropologia i la teologia. Dues són les preocupacions, recurrents, d'aquest estudi: definir el matrimoni i determinar si la naturalesa del matrimoni cristià té alguna cosa que la diferencia de la resta de relacions de parentiu.

El primer capitol s'anomena «Approachess. Es tracta d'una aproximació a la matèria i d'una declaració d'intencions. L'autor es mostra respectuós amb el treball $\mathrm{i}$ les fonts utilitzades per demògrafs $\mathrm{i}$ historiadors socials, però remarca la necessitat de recórrer també a d'altres fonts, com les literàries $\mathrm{i}$ les teològiques, que esdevenen vitals en la seva exposició. Considera que la literatura, sotmesa a una critica rigorosa, proporciona una informació valuosa que, tanmateix, no situa al mateix nivell que les dades que es poden extreure de sermons o tractats. En la seva recerca de les claus del matrimoni medieval explora, sobretot, dret, teologia, lite- tion and it is to be highly recommended in anyone interested in the period around 1200 , in the gendering of the male and specially female bodies and how this is reflected in discourse.

\section{Gillian McClure Blackmore}

ratura $\mathrm{i}$ art. Un repàs a la biografia de santa Caterina de Siena, els sermons de sant Bernardino de Siena (1380-1444), la correspondència mantinguda entre el mercader florentí Francesco de Marco Datini (c. 1335-1410) i la seva esposa Margherita i, per últim, la figura de la mare d'Enric VII, lady Margaret Beaufort, tanquen aquest capitol.

El segon assaig s'anomena "The inheritance, Christian and Romany, Tracta el tema de l'herència que rep el matrimoni medieval: de l'antiguitat, dels jueus, de l'Església primitiva, de Roma i dels pobles "bàrbars". La Bíblia és presentada com la font més adient per conèixer el matrimoni jueu i cristià. La Bíblia i les interpretacions que n'han fet teòlegs, papes... i les corrents de pensament sorgides com a conseqüència d'aquestes interpretacions són comentades aqui. El nostre autor considera que, al segle XII, l'essència del matrimoni, de les seves lleis i doctrines no és més que la reafirmació de posicions de centúries anteriors. En aquest segle es produeix un enfortiment de la legislació matrimonial, perquè des de llavors el matrimoni és un sacrament. I aquí és on aquest capítol enllaça amb el següent, el tercer: The cult of celibacy in the Eleventh and Twelfth centuriess. El celibat, com a valor en alça, positiu, s'ha de relacionar amb la Reforma Gregoriana i amb els corrents més ascètics que pensen el matrimoni. Alguns teòlegs, com Hug 
de Sant Víctor, situen com a model de perfecció, a imitar, la unió entre la Verge Maria i el seu espòs sant Josep. D'altres, seguint, per exemple sant Agustí, fan de la procreació la raó d'ésser de la institució matrimonial. El matrimoni als segles XIXII apareix caracteritzat per cinc punts: té una litúrgia pròpia; una jurisprudència especifica; és definit pels teòlegs com un dels set sacraments; teòlegs i poetes formulen doctrines de l'amor humà on el matrimoni apareix reflectit; $i$, finalment, esdevé vital per poder heretar.

El quart assaig, anomenat The correspondence of Heloise and Abelard $n$, el podem catalogar, a nivell d'unitat temàtica, amb el que segueix: "The marriage of Heloise and Abelards. Brooke no dubta sobre la veracitat de la correspondència matinguda per aquesta parella, que ell utilizza per explicar el matrimoni al segle XII. Aquest segle fou clau en la definició dels costums i de les lleis del matrimoni; l'Església va passar a controlar-lo i la monogàmia va començar a imposar-se. Les noces d'Abelard i d'Eloisa van comportar la corrupció del seu amor. El seu fou un casament secret i vàlid, realitzat en una c̀poca (c. 1116-1117), en què les concubines eren socialment acceptades però condemnades per l'Església. Eloisa havia manifestat clarament el seu desig de ser abans concubina que esposa, en un intent de no enfonsar la carrera d'Abelard. El seu va ser un destí tràgic. Finalment, el seu matrimoni va ser anul.lat. Eloisa va acabar pensant que lamor era mera concupiscència i que el desitjable era l'amistat.

El sisc̀ capítol s'anomena "Marriage in law and practices; en ell Brooke ens parla de dues actituds davant del matrimoni: la dels reis Capets, dels segles XI i XII, i l'eclesiàstica. Ambdós models són extrets de dues obres de l'historiador de l'edat mitjana Georges Duby, Medieval Marriage (1978) i Le chevalier, la fermme et le prêtre (1983). El primer model de Duby, el Capet, ens situa davant d'uns reis, com Luís VI, Lluis VII, Felip II.... que repudien, $i$ canvien per altres, aquelles esposes que no els satisfan. Enfront d'aquest model està l'eclesiàstic, que considera que el matrimoni ha de tenir una finalitat reproductiva i ha de ser monògam; tot $\mathrm{i}$ això la virginitat és valorada com un estat superior. Brooke alaba $\mathrm{i}$ matitsa aquests dos llibres. Ell creu que aquests dos models acaben coincidint quan els regnes passen a ser hereditaris i els fills legitims es transformen en una necessitat. En aquest apartat el nostre historiador també comenta la biografia de Christina de Markyate (c. 1100-1160) i les noces de Mabel de Francheville (c. 1135), les d'Agnès, comtessa d'Oxford (c. 1162-1163), $\mathrm{i}$ les sis bodes del rei Enric VIII.

El setè capítol, anomenat *The use of literary evidence for the History of Marriage: Wolfram yon Eschenbach", forma part de la unitat de contingut dels dos articles que el segueixen, The witness of Chaucer" $\mathrm{i}$ "Love and Marriage in Shakespearex. Aquesta trilogia utilitza la literatura com a evidencia historica, una vegada han estat destriats els elements "reals" dels merament wficticis». De Wolfram von Eschenbach són analitzades dues obres: Parzival i Willehalm. Brooke considera que aquest home, un novel-lista, un laic, realitza el comentari sobre el matrimoni més remarcable de tota l'edat mitjana. A diferència de Li contes del Graal, de Chrétien de Troyes, al Parzival de von Eschenbach apareixen les dues noces de Gahmuret (pare de Parzival), la primera amb una pagana i la segona amb una cristiana; tanmateix, les més interessants són les del mateix Parzival. La recompensa de l'heroi per trobar el Graal és l'amor de la seva esposa Condwiramurs. El seu matrimoni és sinonim de perfecció, perquè es fonamenta en la fidelitat. La major virtut és la lleialtat, i la lleialtat entre els esposos és la major virtut del matrimoni. Wolfram creu que la base del matrimoni es troba en 
l'íntim consentiment; per això, les cerimonies i les fórmules legals són superficials. A la seva obra Willehalm Wolfram tracta el tema del matrimoni amb una pagana conversa. Sant Pau havia declarat aquests matrimonis lícits, el papa Innocenci III (1198-1216), contemporani de Wolfram, ho reafirma. Aquí el novel-lista és ambigu; sembla ser que, en última instància, aposta per la tolerància $\mathrm{i}$, pagans $\mathrm{i}$ cristians, acaben en pau. Finalment, Brooke estudia alguns del contes de Chaucer, els Canterbury Tales. Aquests contenen una gran varietat de problemes matrimonials, són una elaborada exposició de les relacions humanes. En el cas de Shakespeare les obres de teatre seleccionades són quatre: A midsummer night's dream, As you like it, The merchant of Venice i Romeo and Juliet. Aquest escriptor, que el corrent historiogràfic del «New Historicism» ha situat en el centre de les seves recerques, és valorat per Brooke pel seu discurs valent, sincer $i$ arriscat sobre el matrimoni.

El decè capitol s'anomena "The church porch: marriage and architecturen. El nostre autor realitza una interessant contextualització del matrimoni, i el situa en l'espai fisic en el qual tenia lloc. Durant molt de temps Església i sacerdot foren elements prescindibles per celebrar unes noces legitimes. A la baixa edat mitjana les fonts legals ens mostren com molts casaments se celebraven en les cases, o en algun altre lloc, per exemple a la Toulouse dels segles XIV-XV els contractes matrimonials es feien davant notari. Pero, cap a la fi de l'edat mitjana, comencem a trobar algunes esglésies amb pòrtics molt sumptuosos: segons Brooke això es deu al fet que es va estendre el costum de casar-s'hi. Per exemplificar-ho utilitza el conte de Chaucer The wife of Bath.

L'assaig que serveix de cloenda al llibre es titula eTowards a theology of marriages. En ell Brooke hi realitza una petita recapitulació dels testimonis més destacats que ha utilitzat com a fil conductor de la seva historia del matrimoni a l'edat mitjana. La idea cristiana de matrimoni és presentada com el model que humanitza, i que permet elevar la dura realitat social i sexual que caracteritzava el matrimoni; remarca també la importància de la fidelitat. I. l'últim dels seus testimonis, Jan Van Eyck i el seu sensacional retrat del matrimoni Arnolfini (1434). Els esposos Arnolfini, agafats de la mà, són el paradigma del model cristià de matrimoni.

En conclusió, una obra interessant, sens dubte no definitiva, $\mathrm{i}$ que convida a la reflexió d'una temàtica difícil que, en els darrers temps, desperta l'interès dels historiadors.

Núria Silleras Fernández

\section{DuBY, Georges}

Dames du XII siècle. I Aliênor, Héloise, Iseut et quelques autres

París: Gallimard, 1995.175 p.

Traducción castellana: Damas del Siglo XII. Leonor, Eloisa, Iseo y algunas otras Madrid: Alianza, 1995. 144 p.

Presentamos aquí una nueva obra de Georges Duby, Concebido como el primero de una serie de tres volúmenes dedicados a la mujer del siglo XII, este libro bucea en busca de imágenes femeninas. Duby escoge a seis damas, a seis mujeres "que l'on nommait dames parce qu'elles avaient épousé un seigneurn. Algunas de ellas fueron seres reales, históricamente atestiguados, tangibles y visibles por sus contemporáneos y contemporáneas. Otras sólo existieron en la imaginación de aquellos que escuchaban las obras de los novelistas del norte de Francia a finales del siglo XII. 
La obra está basada en textos. Decenas de ellos, que servirán para ofrecer una imagen de cada mujer, de cada dama. No se trata, sin embargo, de textos realizados por mujeres. Duby nos previene de la imagen que estos escritos pueden provocar en nosotros *parce qu'ils sont écrits par des hommes". Apenas nada subsiste de la escritura femenina del medievo, y la que ha llegado hasta nosotros está, en algunos casos, bajo sospecha. $\mathrm{Y}$ sin embargo «les dames du XII siècle savaient écrire, et sans doute mieux que les chevaliers, leurs maris ou leurs frères". ¿Cómo son estos textos utilizados? Ni testamentos, ni ventas, conveniencias o esponsalicios. Todos ellos son textos de memoria, composiciones que son producto de las reflexiones masculinas acerca de lo femenino. Tienen, además, otra característica común: son obras con una intencionalidad pedagógica, adoctrinadora. Fueron escritos para que la gente los entendiera como wune leçon morales.

Antes de comenzar, Duby informa acerca de sus objetivos: presentar siete figuras de mujeres. El libro se estructura en seis capitulos, cada uno de ellos - salvo el último- dedicado a una mujer distinta.

El capítulo inicial nos habla de Leonor de Aquitania, o mejor, de la imagen que de Leonor de Aquitania nos han dejado algunos textos masculinos. Lo primero que vemos es su tumba en la iglesia de Fontevraud. Silenciosa. Acaso su rostro no sea un retrato. No importa. ¿Qué sabemos de ella? Una niña de apenas 13 años que en 1137 es entregada en matrimonio a Luís VII de Francia, de 16. El historiador nos dibuja la escena siguiendo los textos que acerca de ella escribieron los hombres de iglesia entre 1185 y 1200. ¿Qué nos dicen estos escritos? Ella es una mujer. Para los hombres del siglo XII eso es lo mismo que afirmar que es una criatura malvada, causante, como todas, del pecado del mundo. Además era nieta de Guillermo IX, duque de Aquitania: el tro- vador. Ya está condenada. Hay algo más. Su divorcio, en 1152, fue un suceso que conmocionó a media Europa. También, hacia 1170 , podemos verla junto a sus hijos haciendo frente a su esposo Enrique II de Inglaterra. Justifican todos estos hechos la imagen que se proyecta de ella (la incestuosa, la encarnación de la lujuria, la bigama...)? ¿A qué composiciones hemos de creer, a estos textos o a las obras trovadorescas aquitanas? Quizí ambas son sospechosas. Duby, tras realizar un recorrido rápido por la vida de esta mujer, da un juicio salomónico: *j' inclinerais plutôt à la plaindrex.

En el capítulo segundo se analizan los sermones escritos desde el siglo XII para ser leidos el día 22 de julio. Duby presenta a María Magdalena, una prostituta arrepentida y perdonada. Los sermones dejan deslizar de forma peligrosa aquellos rasgos de las mujeres que más inquietan a los hombres. María Magdalena es recordada por su amor hacia un hombre: "douce, amoreuse, trovait... dans le Christ, vrai amant que trés ardemment elle aimait...n. La narración de los eclesiásticos es un texto uniforme, ordenado. En él aparecen todas las virtudes de esta arrepentida: su entrega a Cristo, su amor. su abnegación, su entera devoción. El lector del libro se deja seducir por la imagen que cree entender: siglo XII, ¿exaltación de las mujeres en el culto mariano? De ninguna manera. ¿Qué imagen debía proyectar esta enumeración de virtudes en la mente de los hombres? Porque - y aquí se remite a los trabajos de Nicole Bériouel público de estos textos no estaba formado por mujeres. La narración de los eclesiásticos forma parte de una estrategia discursiva creada en el siglo XII para reconducir a la sociedad masculina hacia el camino recto. María Magdalena encarna a la antimujer, a aquella que es capaz de reprimir todos los vicios femeninos y abandonarse al amor por Cristo. Su vida no fue recopilada para que las mujeres la imitaran (al fin y al cabo, jno es una pros- 
tituta un ejemplo peligroso?) sino para avergonzar a los oyentes, a los hombres, poniendo ante sus ojos a una mujer que era mejor que ellos. El culto mariano no se difunde para mayor gloria de las mujeres, sino para vergúenza de los hombres.

En el capítulo tercero llegamos por fin al punto culminante, al centro del libro (p. 73-110). Aquí sitúa Duby a la dama que todos queríamos encontrar: Eloisa. No hay tema más clásico ni más trabajado que éste en la historiografia sobre la mujer medieval. Acaso puede decirse algo nuevo? Duby deberá posicionarse. Desde su aparición, las cartas de Abelardo y Elósa han despertado los más encarnizados debates entre los medievalistas: ;fueron escritas por Pedro Abelardo? ,Por Jean de Meung? ¿Por Andrés el Capellán? ¿Son una invención del siglo xIII? Georges Duby fija su mirada sobre una parte de la correspondencia. Estamos en 1142. Pedro Abelardo, presionado por la edad - tenía entonces sesenta y tres afios-y por la condena de su obra, ha muerto. Otro Pedro, éste abad de Cluny, escribe una carta a Eloísa, esposa del difunto. Una carta de consuelo, para informarla, para reconfortarla. Le explica cómo transcurrieron los últimos días de Abelardo, entre la humildad y la contemplación. Un ejemplo para todos. Sin duda había lavado todas sus culpas. ¿Cuáles son éstas? El abad habla ahora de Eloísa, enclaustrada, fiel a Cristo, que ha pasado de ser una mujer seducida por la «copulation charnellen a convertirse en una "femme philosophiquer. Esta última imagen que nos ofrece el abad Pedro de Cluny no es, sin duda, la que ha perdurado hasta nosotros. Desde Jean de Meung hasta el siglo XIX el nombre de Eloísa ha estado ligado a la concupiscencia, al ardor femenino. Pero también a la rebeldía, a la inteligencia, a aquello que representa el lado más peligroso de la mujer. ¿Cómo explica Duby el mito de Eloísa? La correspondencia es una novela. Abelardo es el héroe. Eloísa la razón última de sus desgracias. ¿Acaso no era Pedro Abelardo el filósofo más famoso de su tiempo hasta que topó con esa mujer y se abandonó a los placeres de la carne? La correspondencia está construida como un todo unicario, como un texto moralizante que quiere exponer cuáles son los actos que debe seguir todo hombre; así como el peligro que entraña ignorarlos. Primero el hombre debe acercarse al placer femenino solamente tras el matrimonio, que debe realizarse, además, de forma solemne, pública. Segundo: este matrimonio ha de llevarse a cabo con el mutuo acuerdo de los cónyuges. Tercero: el acto sexual sólo es justificable, incluso tras el matrimonio, obedeciendo a las necesidades de la procreación. ¿Acaso no transgredió Pedro Abelardo, el hombre encumbrado por la fama, soberbio, poderoso con su palabra, casi inmortal, todas estas premisas? Ni tan solo él, que todo lo podía en la tierra, pudo escapar de aquel que todo lo gobierna desde los cielos. Éste es, en definitiva, el mensaje moral de esta correspondencia, de esta - Duby lo repite- novela.

En el capítulo cuarto se habla de Iseo. Inicia Duby sus pesquisas: :Cómo es posible que la imagen de Iseo haya eclipsado a la de Tristán? ¿Era así en el siglo XII? ¿Cómo rescatar su verdadera imagen? Lo primero, es verla con los ojos de un hombre del siglo XII, como aquellos que compusieron esta novela - El Tristán e Iseo-. Debemos, por lo tanto, descubrir cuál era el sistema de valores que movía a esta sociedad. Después, buscar su verdadera imagen.

Las novelas, esos relatos, esos divertimentos, kavaient mission, en distrayant, d'enseigner à se bien conduires. Pero ante todo, la literatura caballeresca fue escrita por hombres y principalmente para ellos. El héroe es, por tanto, el personaje masculino. ¿Quién es Iseo en realidad? Ella encarna la imagen que los caballeros célibes, los jóvenes, tenían de aquellas mujeres a las que deseaban: casadas, ardientes y poderosas. Pero también - Duby nos 
lo recuerda- estériles, pues en toda la novela no se alude en absoluto a la que es la función primordial de la mujer casada - e Isolda lo era-: la procreación. ¿Fornicación con una mujer casada? Sin duda aquellos que actuen como Tristán e Iseo están condenados para siempre. Duby se apresura a explicarlo. Estos amantes fueron, según la novela, víctimas del deseo, adquirido de manera forruita mediante un filtro de amor. No hay de que preocuparse: udu désir, ravageur, nul n'est responsable. Nul n'est pécheur. Ne le sont donc ni les chevaliers qui poursuivent les dames ni les épouses qui se laissent aller à trahir leur seigneur et maitres. Así estamos ante otro texto moralizador que desea dirigir la conducta de los hombres. ¿De todos? No. Sólo la de aquellos aristócratas que, desposeidos por sus hermanos (que son los primogénitos, los casados) esperan pacientemente la oportunidad de hacerse con una rica heredera: los jóvenes, los caballeros.

Capítulo quinto. Otro ejemplo distinto. Se trata de un error, de un relato condenado. Poco conocida, poco comentada, Juette aparece, de la mano de Duby, ante nuestros ojos. Una mística, una devota. La conocemos por su última confesión, susurrada al oído de un religioso de Floreffe, el cual la redactó en latín. De nuevo un texto. ¿Es un escrito femenino? No. Este hombre tradujo del vulgar al latín y adaptó la narración de Juette al discurso hagiográfico. ¿Qué sabemos de la existencia de esta mujer? ¿Qué imagen nos proporciona el texto, compuesto hacia 1230 ? Juette era una dama. Entregada a los 13 ắos ecette enfant s'était laissé donner, elle s'était laissé prendreo. Sin embargo - la expresión es de Duby - tuvo suerte: enviudó a los 16 años, tras tres años de matrimonio $y$ varios hijos en su haber. La familia desea volver a casarla. Una mujer joven que ha demostrado sobradamente su fertilidad es un bien precioso. Ella se niega y como coartada acepta una vida de sumisión a Cristo.
El texto de Juette nos sitúa ante las nuevas realidades del momento. En esta Europa de las catedrales también las mujeres participan de ellas: el dinero comienza a filtrarse sólidamente en esta sociedad. Omnipresente, es una tentación demasiado grande. Juette se deja llevar por el deseo de enriquecerse. "C'était mal". Ciertamente. Ella se arrepiente entonces y decide retirarse de este mundo, encerrándose en una leprosería. Allí comparte con los enfermos sus sufrimientos, sus pesares, pero también sus ropas y su comida. Pronto se cansa. Demasiado fácil. Decide entonces emparedarse, aislada, cerca de la leproseria, aunque rodeada de sirvientas, pues no es necesario renunciar al confort de la vida burguesa. Duby ironiza: "ce qu'elle voulait c'était la solitudes. Aquí transcurrirá toda su vida, presenciando apariciones $y$ realizando viajes místicos al Reino Celeste, donde la Virgen la acoge con frecuencia. En una ocasión el apóstol Juan celebró misa ante ella. El rumor corrió por toda la región. Los eclesiásticos la asediaban a preguntas. Se decía que conocía el pasado y que veía, a través de las cortinas del tiempo, el futuro. Algún monje llegó incluso a enamorarse de ella. Irritada, no deseaba saber nada de los hombres. Simultáneamente cientos de mujeres, procedentes de la aristocracia algunas, admiradoras otras, miméticas las demás, comenzaron a construir comunidades de devoción. Juette canaliza este movimiento hacia la leproseria. «Elle fit de celle-ci, sous sa lourde domination, comme une citadelle de la liberté féminine». Las limosnas, suculentas, llegan por doquier, $y$ la Iglesia oficial reacciona atacando a la mística, la cuál, una noche y de la mano de María Magdalena fue conducida al Paraiso. Sin embargo, la Iglesia no dudó en condenarla, consciente del peligro que suponía la difusión de su ejemplo entre las mujeres. "La visionnaire fut oubliée. Le pouvoir, le vrai, demeura en mains masculinesn. 
En el capítulo sexto Duby nos invita a descubrir a otra mujer. De hecho son dos mujeres: Soredamor y Fenice, aunque se presentan bajo un mismo prisma: "Ces deux images de femmes, en realité, s'en font qu'unes. El Cligés, novela escrita alrededor de 1176 por Chrétien de Troyes, es el cscenario de este capítulo. Duby nos presenta a los personajes. Fenice es heredera del emperador de Occidente. Soredamor es hermana de Gauvain, el mejor caballero del mundo. El contenido de la novela es sobradamente conocido. No lo resumiremos aquí. Duby lo hace de forma magistral. Sólo deben destacarse las reflexiones más importantes. Primero: la iniciativa de la novela está en manos de las mujeres. Ellas son ejecutoras o introductoras de la trama. Su actuación es determinante en cada momento (la mediación de la reina Ginebra, los filtros que prepara Thessala, el asalto de las mujeres al palacio...). Duby muestra su asombro: «j ai longtemps combattu, et durement, l'hypothèse d'une promotion de la femme à l'époque féodalen. Sin embargo las imágenes que proyecta esta novela son indudables. Así lo cree el historiador: «je cèdew. Segundo: hacia 1176 estas novelas eran un eficaz medio de comunicación, de educación de las élites aristocráticas que se agolpaban alrededor del monarca. Los caballeros, seducidos por estos relatos, están comenzando a modificar sus costumbres: "le progrès de toutes les choses les a lentement civilisés?. Poco a poco estos hombres se ven inclinados a cambiar su actitud ante las mujeres, a *contenir ses pulsionsw. Otro dato favorece este hecho: la incursión del dinero - ya hemos hablado de ésto- en todas las escenas de lo cotidiano propició una disminución del valor de la tierra sustituido por el valor del dinero. Ello permitió modificaciones en las costumbres matrimoniales. Se trata, en último término, del paso del esponsalicio a la dote, que se opera en estos últimos años del siglo XII.

Duby concluye esta primera obra con un pequeño epílogo, un corto resumen en el que explica qué imágenes deben fijarse tras la lectura del libro. Para los hombres del siglo XII "la fernme d'abord est un objectr. Por eso los hombres controlan sus cuerpos, controlan su tiempo. Pero también la mujer es un ser temido, porque aon ne sait pas ce qu'elle a dans la têter. Existe, sin embargo, algo positivo en ellas: su ternura, que lleva al hombre a amarlas.

Para finalizar, debe decirse que se trata de un libro excelente. Las fuentes que Duby ha urilizado para la confección de su obra le han permitido moverse con gran libertad, pues no se trata de textos estrictamente femeninos, sino utilizando documentos de memoria (reflexiones masculinas sobre algunas mujeres). El lector que lea esta obra la encontrará muy discinta a los primeros trabajos sobre el tema realizados por el mismo autor. Dames du XII siècle es, sin duda, un libro mucho más recomendable.

\section{F.J. Rodriguez-Bernal}

\section{AURELL, Martin}

Les noces du comte. Marriage et pouvoir en Catalogne (785-1213) París: Publications de la Sorbonne, 1995. 623 p.

Resulta dificil para este lector definir, a su entera satisfacción o con el rigor que el caso requiere, en qué punto el bello libro de Martin Aurell renueva el conocimiento de la historia de Caraluña de los siglos VIII al XIII. Es un proyecto ambi- cioso, y bien dirigido, con la adecuada metodología y la necesaria erudición para hacerlo posible. Si uno se deja llevar por una primera impresión, que de inmediato descubrirá que es falsa, cree que se encuentra en una típica obra de historio- 
grafia francesa dedicada a un tema muy concreto, en este caso, las diferentes formas de alianza matrimonial de la casa condal de Barcelona; pero algo le hace sospechar que tras este escenario, el autor reflexiona sobre cuestiones de mayor calado, que afectan a la realidad histórica de Cataluña en sus primeros momentos. Como medievalista que es, Aurell organiza el material documental en su entorno para descifrar el tema clegido, y se enzarza en elegantes precisiones sobre las lecturas que han posibilitado su renovado acercamiento. Las deudas son importantes, no duda en confesarlo desde el primer momento, con los clásicos de la historiografia medieval catalana, y con los autores modernos que están renovando con prudencia pero con precisión muchos aspectos del pasado catalán hasta ahora poco claros. El porvenir de los estudios sobre la Cataluña medieval, si nos atenemos al diagnóstico ofrecido en esta importante obra, es magnífico: prueba de la buena salud de un pais y de sus instituciones. Situado así el enclave preciso del que parte Aurell, veamos el objeto de sus pesquisas, y sus resultados.

En su opinión, la primera articulación de Cataluña, la de los siglos VII al XII, se realiza en torno a las alianzas matrimoniales, y a los sistemas de parentesco en las que ellas se inscriben. Resulta facil reconocer tres momentos diferentes en la articulación de estas alianzas matrimoniales, que se relacionan estrechamente con la manera de entender la unidad familiar.

En un primer momento, en los siglos vil al $\mathrm{x}$, las alianzas matrimoniales tienden a una cierta endogamia, resultado de una estructura familiar tipo sippe, donde los hombres y las mujeres tienen derechos patrimoniales muy parecidos y las relaciones son de carácter horizontal, acercándose entre si los parientes consanguíneos cuando cualquier peligro, real o imaginario, amenazaba a sus tierras. En este sentido, las mujeres ocupan un papel importante; más aún, decisivo. Eran mujeres que idolatraban a sus hijos, como muestra el caso de Duodha, esa gran dama catalana que escribe un manual de educación y sentimientos maternales, único en su género, $y$ donde la escritura femenina aparece con toda intensidad; mujeres que consideraban un alto privilegio anularse como tales y desarrollar la imagen familiar, con lo que la figura femenina se fue engrandeciendo poco a poco. Algunas resultaron claves en su papel de kcentro de la consolidación patrimonials; muchas de ellas recibieron grandes dotes, y casi todas estuvicron a la altura de las circunstancias políticas que les tocaron vivir. Sus encantos suscitaron comentarios y crearon leyendas, con las que se trataba de comprender el importante papel jugado por ellas en la articulación de una sociedad que en otro sentido exaltaba la virilidad en la conducta social y cultural. En algunas ocasiones, estas grandes damas de la primitiva aristocracia catalana, llevadas por su piedad, fomentaron la vida religiosa y monástica. Es el caso de Emma, fundadora del monasterio de Sant Joan de les Abadesses, o de Adelaida, la abadesa reformadora. No existieron jamás mujeres más abnegadas que éstas, y fue una suerte contar con ellas en los difíciles momentos que pasó el pais en tiempos de Guifré el Pilós.

El segundo momento corresponde a los siglos X y XI, y tiene que ver con la progresiva influencia de la moral de la Iglesia en los asuntos matrimoniales. La estructura familiar cambio radicalmente hacia el año 900. El linaje, que es un sistema patrilineal, donde se da prioridad a las relaciones de filiación con los descendientes, creará un nuevo orden político, y será el origen de las graves disputas territoriales que sacuden este período. La necesidad de buenos matrimonios que consoliden el linaje obliga a buscar esposas lejos $y$, por consiguiente, a practicar la exogamia. La llegada de importantes mujeres del otro lado de los Pirineos, como Ermessendis de Carcassona o 
Almodis de la Marca, o de princesas de Castilla, como Sancha, la mujer de Berenguer Ramon I, constituye el patrón que se seguirá por la práctica totalidad de los linajes nobiliarios catalanes. Los ejemplos elegidos por Aurell prueban que, en efecto, el linaje de los condes de Barcelona (desde Guifré el Pilós hasta el malogrado Ramon Berenguer II Cap d'Estopes) utiliza el matrimonio con mujeres de la alta aristocracia de su tiempo para consolidar el poder sobre el territorio. La reforma gregoriana diseñó además un modelo de matrimonio, con presencia del sacerdote, que favorecía este sistema de articulación familiar, basado en la primacía del padre de familia, $y$ de su primogénito varón. Las luchas de los gineceos por buscar herencias a los hijos segundones, a los que por derecho no iban a heredar el núdeo principal del linaje, constituye una constante de estos siglos: un conflicto a veces sordo y áspero que tiene lugar en el interior del espacio doméstico, en la privacy de estos aristócratas, y que da lugar a un hecho bastante insólito, y de ese modo lo resalta el propio Aurell, la inclinación al smatricidion, en lugar del parricidio, en la sociedad catalana de aquel tiempo.

El tercer período, denominado la evictoria de la política", corresponde en términos generales al siglo XII, y más concretamente desde 1127 a 1213. Las fechas corresponden, la de su comienzo, a la estrategia ideada por Ramon Berenguer III para consolidar sus dominios, y la final, a la conocida batalla de Muret, en la que el rey Pere el Caròlic muere a manos de Simón de Montfort.
El programa matrimonial consiste en articular el linaje condal, de tal modo que permita construir una nación con fisonomía de tal, Cataluńa. Las damas parecen encontrarse en apuros en estos tiempos, su status social y juridico declina debido a la presencia del derecho romano, que es claramente misógino, y a la aparición de la dote, que va sustituyendo poco a poco al esponsalicio, con lo que las mujeres van siendo relegadas a un papel secundario, hasta alcanzar una situación dramática en el caso de la desafortunada María de Montpellier, la madre de Jaume I.

Estos son, en síntesis, algunos de los planteamientos sugeridos en este libro. Uno de los aspectos que más sorprende es su absoluto rigor a la hora de tratar temas que resultan opacos en la documentación. Prucba del gran oficio de este joven y brillante historiador catalán afincado en Francia, como catedrático de Historia Medieval en la Universidad de Poitiers. Al principio, su audacia resulta sorprendente, aunque muy pronto se descubre que tenía sobrados conocimientos como para ofrecer esta interpretación de la historia de Cataluńa a partir de las maneras de contraer matrimonio del linaje condal. Recomiendo la lectura de este libro, que me gustaría ver pronto en lengua catalana, para que el público de nuestro país pudiera comprobar por si mismo la riqueza de su trabajo y el espíritu de renovación: aspectos ambos tan característicos del modo de ser catalán, al que Aurell rinde un sentido homenaje.

J.E. Ruiz-Domènec

Cameron, Averil

Christianity and the Rhetoric of Empire: The Development of Christian Discourse Berkeley; Los Angeles: University of California Press, 1991 (Sather and Classical Lectures; 55). XV, 261 p.

En 1959, Arnaldo Momigliano, interessat en els canvis culturals i religiosos que es produiren a la sociecat romana del segle IV, revisà en una conferència pronun- 
ciada a la Universitat de Cincinnati, publicada com a capítol introductori ( Introduction. Christianity and the Decline of the Roman Empirex) del llibre The Conflict Between Paganism and Christianity in the Fourth Century (trad. en castellà, Madrid: Alianza Editorial, 1989), la interpretació d'Edward Gibbon, escrita durant l'època de la revolució nord-americana (Decline and Fall of the Roman Empire), sobre la influència del cristianisme en la decadència de l'Imperi romà. Segons Momigliano, calia superar la interpretació negativa del procés de cristianització de l'Imperi romà i mesurar l'impacte real del cristianisme en la societat romana.

Aquesta perspectiva fou recollida el 1971 pel seu deixeble Peter Brown a The World of Late Antiquity: From Marcus Aurelius to Muhammad (trad. en castellà, Madrid: Taurus, 1989), on va estudiar les causes i les consequències, tant a curt com a llarg termini, del canvi social i cultural que es produí al segle III a la societat romana, emfatitzant el contrast entre la zona oriental (area ortodoxa) i la zona occidental, i el desenvolupament de l'Església cristiana i el seu paper central en la política, la societat i la cultura de l'antiguitat tardana. A The Making of Late Antiquity (Cambridge and London: Harvard University Press, 1978), The Cult of Saints: Its Rise and Function in Latin Christianity (London: Student Christian Movement Press, 1981) i Society and the Holy Antiquity (London: Faber and Faber, 1982), P. Brown situa l'estudi dels canvis en la sensibilitat religiosa dels segles II-IV en el centre de qualsevol explicació sobre l'estil de vida religiós, cultural i social de lantiguitat tardana.

En el debat historiografic suscitat sobre la natura de les transformacions que donaren lloc a laparició de l'antiguitat tardana i al desenvolupament del cristianisme al baix imperi, els treballs d'Averil Cameron subratllen la importancia de la ideologia en el procés de canvi històric.
Professora del King's College de Londres, començà la seva obra tot seguint la línia d'investigació traçada per A. Momigliano al seu ja cèlebre article «Pagan and Christian Historiography in the Fourth Century A.D.s, publicat a The Conflict Between Paganism and Christianity in the Fourth Century (1963), amb l'estudi de I'historiografia bizantina del segle VI (Agaties i Procopi): Agathias (Oxford: The Clarendon Press, 1970) i Procopius and the Sixth Centzory (London: Duckworth, 1985). La seva reflexió metodològica, sobre l'anàlisi de l'escriptura de la història i la posició crítica de l'historiador davant del text, es completa amb l'obra col-lectiva History as Text. The Writing of Ancient History (London: Duckworth, 1989).

A mitjan dels anys vuitanta, interessada en la possibilitat de fer una història dels gèneres literaris cristians a l'Antiguitat tardana, assenyalà el significat del discurs cristià en el canvi social (en el sentit proposat per Michel Foucault de com el cristianisme va arribar a articular un discurs totalitzant), i suggerí la necessitat d'una nova interpretació històrica dels textos del cristianisme primitiu ( Redrawing the Map: Early Christian Territory After Foucaultw, Journal of Roman Studies, 76, 1986 , p. 266-271). Aquest article va constituir l'esbós programatic de Christianity and the Rhetoric of Empire: The Development of Christian Discourse, on la creació del discurs cristià apareix com l'objecte d'estudi per a la comprensió, des d'un punt de vista històric, del desenvolupament del cristianisme primitiu dins el context del món romà. L'estudi comprèn des dels seus inicis al segle $\mathrm{I}$, amb referències als textos del Nou Testament, a la totalització del discurs cristià al món bizantí del segle vı. Amb especial atenció pel procés mitjançant el qual la retòrica cristiana es convertí en una retòrica del poder (segle IV), i a la connexió entre la cristianització de I'Imperi i la natura de la representació del món bizantí inicial. 
Al primer capitol (How Many Rhetorios?, p. 15-46) la professora Averil Cameron discrepa de la visió d'una anomenada cultura popular (escriptura cristiana) victoriosa enfront d'una cultura pagana d'elit, de la qualificació de l'antiguitat tardana com a època de isuperstición i com a кirracionals, així com de la decadència de la societat clàssica. Analizza el poder social de persuasió del discurs cristià (segons l'autora aquelles estratègies retòriques i formes d'expressió caracteristiques de l'escriptura cristiana) en la seva recepció a la societat romana, i estableix un estret lligam entre predicació $i$ text. Al segle n, els cristians, mitjançant la dialèctica entre fe cristiana i visió cristiana del món, constrüren ideològicament un discurs, amb la voluntat d'emprendre una tasca de cristianiczació de la societat romana, que provocà un dels canvis culturals més grans que han marcat l'esdevenir de la historia occidental. En la construcció d'aquest nou món tingué més importància l'ensenyança cristiana (moral i doctrinal), mitjançant el llenguatge oral, escrit i visual, que la conducta de la comunitat cristiana (mode de vida i disciplina comunal).

El segon i el tercer capítol tracten de la formació del discurs cristia als segles II i III. Al segon capítol (Showing and Telling, p. 47-88) s' indica el caracter figuratiu (afiguralin) i declaratori ("declaratoryn) del llenguarge cristià. La metafora i la imatge constituïren el recurs literari caracteristic de l'escriptura cristiana. Es recorregué a elles per tal d'expressar el missatge cristià, els misteris inexplicables de la fe cristiana. La Biblia subministrà un repertori de simbols i d'imatges als escriptors cristians i a l'art visual. El miracle i la paràbola, juntament amb la metàfora $i$ la imatge, foren els recursos retórics emprats pel discurs cristià a l'hora d'explicar la relació entre allò humà $i$ allo diví. Aviat es produi el debat entre els teòlegs cristians sobre la conveniència d'incidir en la vessant paradoxal del discurs cristià en comptes d'apropar-ho al llenguatge de la retòrica clàssica, i aixíf fer-ho més entenedor entre els pagans. La formació d'un discurs totalitzant nasqué de la tensió entre ambdós impulsos. Alhora s'assenvalen les relacions entre Yoratoria clàssica (epideixi) i la predicació cristiana: amb l'apropiació dels elements retòrics classsics de la segona sofistica per part dels escriptors cristians. Al tercer capitol (Stories People Want, p. 89-119) es destaca la influència de les narracions apòcrifes en el desenvolupament del discurs cristià i en la formació d'un univers cristià del mite. La raó d'aquesta importància és significativa: els textos apòcrifs proporcionaren una informació complementària als creients i donaren resposta a molts dels interrogants que havien suscitat els evangelis. Pel seu contingut són expressió de les noves formes de l'escriptura cristiana que des de final del segle II trobaren en la narració biogràfica un model literari molt més àgil d'expressió i de confirmació de la fe. D'altra banda, la diferència entre els textos apócrifs i la novel la antiga se situa en la suposició de la veracitat de la narració: on els textos cristians pertanyen al camp de la veracitat desitjada i les novel.les antigues, al de la ficció.

El quart capitol (The Power over the Past, p. 120-154) reflecteix la capacitat dels oradors i escriptors cristians (cal destacar els bisbes) per adaptar els elements del discurs polític i de l'oratòria pública pagana, $\mathrm{i}$ aixi convertir la retòrica cristiana en una retòrica del poder. En el debat polític la historiografia cristiana del segle Iv (Eusebi i Lactanci) va reinterpretar el passat en relació amb el seu discurs politic de suport imperial, tot demostrant la incompatibilitat del cristianisme amb el sistema de govern imperial. Durant aquest període (segle IV) es desenvolupà una nova forma literaria: les vides de sants. Aquestes oferiren als cristians els ideals de conducta a seguir, a imitació de Crist. Les vides del present eren interpretades en relació amb les vides sagrades del passat.

Al cinquè capitol (The Rhetoric of Paradox, p. 155-188) Averil Cameron 
tracta el paper de la paradoxa a la literatura cristiana dels segles IV i vi. Es fixa en la lluita dels escriptors cristians (per ex. Gregori de Nazianz i Gregori de Nissa) contra el problema de la representació lingüística de Déu i en la solució donada amb la representació simbolica visual, com a mitjà alternatiu d'expressió de la fe religiosa. Això suposa la victòria de l'element paradoxal en el discurs cristià enfront de l'impuls d'assimilació amb la retòrica pública (la paradoxa va tenir un gran pes en el pensament religiós bizantí). Els exemples se centren al voltant dels grans debats doctrinals d'aquesta època: l'encarnació de Déu i la virginitat de Maria. El discurs de la virginitat va obrir el debat sobre la sexualitat, el celibat i el matrimoni, que tan bé ha estudiat Peter Brown a The Body and Society: Men, Women and Sexual Renunciation in the Early Church (trad. en castellà, Barcelona: Muchnik, 1993).

Al sisè capítol (Toward a New Representation, p. 189-221), amb el qual conclou el llibre, es verifica el procés formatiu del discurs cristià: la seva totalització. Quins són els aspectes concrets resultants a Bizanci en temps de l'emperador Justinià? 1) L'origen diví de l'autoricat de l'emperador, qui actua per inspiració divina; 2) El pensament dogmatic i l'ortodoxia religiosa; 3 ) Consolidació de la tendència figurativa amb el creixement d'imatges religioses (icones). La base teòrica de les obres del pseudoDionís, l'Aeropagita, van contribuir a la representació visual, amb la importància de la revelació mitjançant els signes de Déu, i a l'autoritat política, amb la idea de jerarquia.

Per últim, dos detalls: l'absència del debat religiós de la lluita contre l'heretgia a l'interior de l'Església, i l'aprofundiment en els textos i autors grecs, tradicionalment més allunyats dels historiadors de tradició llatina.

\section{Javier Robles Montesinos}

\section{DRONKE, Peter}

Women writers of the Middle Ages: A Critical Study of Texts

from Perpetua $(+203)$ to Marguerite Porete $(+1310)$

Cambridge: Cambridge University Press, 1984. XI, 338 p.

Traducción en castellano: Las escritoras de La Edad Media

Barcelona: Crítica, 1994, 439 p.

En los últimos diez años el interés por el mundo femenino ha dado lugar a un importante volumen de obras en las que se rescataba del pasado a la mujer. Los medievalistas no han sido ajenos al fenómeno y el mercado se ha visto saturado por un sin fin de títulos tras los cuales, como siempre ocurre en estas ocasiones, se ocultaban buenos y malos trabajos.

Historias de las mujeres, las que se quieran. La mayor parte de ellas poco rigurosas en lo científico y, la minoría que escapa de la mediocridad peca de lo mismo, habla demasiado sobre la mujer y poco de lo conservado y hecho por ella. El profesor Peter Dronke, en su obra, ha eludido ambos peligros.

Este crudito nacido hace 62 años y en la actualidad catedrático de Literatura Medieval en la Universidad de Cambridge, nos presenta en estas páginas auténticos testimonios personales no masculinos y si femeninos.

Dividido en dos grandes bloques, su libro analiza meticulosamente cada uno de los textos nacidos de la mano y mente de estas mujeres.

En el primero nos presenta a las protagonistas. Nombremos a algunas de ellas: 
Perpetua, la mártir cristiana muerta en el 203 de nuestra cra. Duoda, condesa de Barcelona y Septimania que en el siglo IX en su Liber Manualis plasmó dos hechos que marcaron su vida: su condición de esposa abandonada por su marido y el papel de madre a través de los ideales de lealtad aconsejados a su hijo. La canonesa del convento de Gandersheim, Roswita, que en el siglo $X$ supo plasmar perfectamente en sus escritos circunstancias personales desde su propia feminidad.

El capítulo más extenso es para la gran Hildegarda de Bingen que, entre otras muchas cosas, mostró una gran preocupación por relacionar la sexualidad de las mujeres con su temperamento y su psicología, lo que, en opinión del profesor Dronke, no tuvo equivalente entre los hombres que escribieron tratados de medicina.

La segunda parte del trabajo es tal vez la más importante, pues nos ofrece una exquisita reproducción de textos, aquellos que el autor ha seleccionado por considerarlos más relevantes; los pasajes autobiográficos de la Vita de Hildegarda; los testimonios de mujeres procedentes del registro de Jacques Fournier: Grazida de Lizer, Mengarde Buscalh, Guillemett Bathégan, Aute Fauré. Finalizando con los pasajes líricos de Le mirouer des simples ames, obra de Margarita Porete.

Primordial aportación de la que carecen la mayoría de trabajos que sobre la mujer y la edad media se han venido publicando y que han ignorado, error, la vital necesidad de dar a conocer las fuentes.

El autor es sincero en su objetivo. Así nos lo demuestra cuando comprobamos que su atención va dirigida al interés autobiográfico e intelectual de estos textos femeninos en los que ellas nos cuentan cómo se ven a si mismas y a su mundo. Sus modos de expresarse y de autoexpresarse.

En resumen, Dronke solo pretende aproximarnos, con la mayor nitidez posible, a una amplia gama de testimonios y emociones de tal forma que, en un futuro, se pueda dar lugar a análisis más profundos. Para él queda claro, tal vez lo que más, que ellas escribieron no guiadas por falsas pretensiones literarias y sí por algo mucho más serio y urgente si se quiere. Al contrario de los varones, ellas lo hicieron por necesidad. Una necesidad interior y no una inclinación artística como otros historiadores e historiadoras, lo cual es más grave, han pretendido.

Esa es la razón por la que el profesor Dronke no ha caido en el error $y$ ha logrado acercarse un poco más al otro lado. Se situa en el núcleo del problema: ellas se autoexaminaban con mayor concreción y profundidad que muchos de sus contemporáneos. Precisamente este sexto sentido es el que confiere a estos escritos femeninos unas cualidades ante las que cualquier defecto técnico palidece.

En su día, un hombre dijo que nuestras vidas siguen los surcos que los muertos marcaron con sus uñas. Cierto. Pero lo que está claro es que obras como la aquí presentada lograrán que, tarde o temprano, tengamos que volver sobre nuestras propias huellas y reandar ya no en soledad, ahora de la mano de ellas, otra vez esos surcos.

Xavier Gil Román

\section{SEBASTIAN, Santiago}

Mensaje simbolico del arte medieval. Arquitectura, iconografia, liturgia Madrid: Ediciones Encuentro, 1994, 440 p.

Dentro del conjunto de obras que Ediciones Encuentro dedica al simbolis- mo del románico, ésta es una producción propia, es decir, de autor español. Se trata 
de una obra que comprende mucho más $y$ mucho menos de lo que su título indica. Mucho más porque de los once capítulos de que consta el libro, solo los cinco últimos están dedicados estrictamente al arte medieval. Los tres primeros los dedica a planteamientos generales sobre simbolismo, iconografia y liturgia, y los tres siguientes a antecedentes históricos: los mundos judío, paleocristiano y bizantino. Los otros cinco los dedica a la época altomedieval, la iconografía medieval, el románico, el auge del gótico y la baja edad media. Y mucho menos porque, a mi juicio, hay muy poco sobre el mensaje del simbolismo del mundo medieval.

Vayamos por partes. El libro es una excelente obra de divulgación sobre los temas arriba expuestos que va desarrollando yuxtaponiendo cronológicamente, a partir del capítulo cuarto, los diversos estudios e investigaciones que el autor cree más importantes y que va comentando $y$, a veces, comparando. Algunos de estos estudios son del propio autor. Pero salvando estos casos, el libro no es un libro de investigación global por parte del autor $y$ si bien quedan expuestos sus puntos de vista parciales, no hay una síntesis de ellos. De ahí que cada aspecto se centre en sí mismo y no se ponga en relación con los otros. Esto tiene como consecuencia que, por cjemplo, en el capítulo primero se haga un resumen de lo que es el simbolismo según los autores que, por renombre o por ser los publicados, deben ser tenidos en cuenta - Jung, Eliade, Chevalier, etc. - y luego, en los capítulos concretos de arte medieval, no veamos la aplicación de este simbolismo por ninguna parte. $\mathrm{O}$ que se nos explique la sacralidad judía o el arte bizantino, sin que luego se nos diga qué relación tienen con el arte románico o gótico.

El autor quiere destacar la importancia de la fuerte relación entre arte y liturgia, ya que considera que buena parte del arte medieval es un arte litúrgico. Pero precisamente por compartir este criterio, el libro decepciona en este aspecto. Salvo algunos ejemplos concretos en que el autor cita las investigaciones propias y de otros sobre la relación concreta entre liturgia $y$ arquitectura, en el resto del libro ambos aspectos se desarrollan paralelamente sin que lleguen a encontrarse. Así, toda la descripción del simbolismo de la liturgia y del templo de Honorio de Autun parece como una abstracción aplicada a la liturgia o al templo de cualquier época o estilo y no acabo de ver, por lo menos en el resumen hecho por Sebastián, qué relación concreta hay entre la explicación del teólogo y algún programa arquitectónico o iconográfico del siglo XII $y$, por ejemplo, continuamos sin enterarnos de la función litúrgica especifica de los murales románicos, cuyo sentido simbólico concreto aún está por revelársenos. La tendencia general a poner en relación los textos escritos de la época con las obras de arte concretas creo que debe ser revisada ya que, por lo menos hasta el románico incluido, muchísimas veces no encajan. La obra de arte fue la expresión de un mundo que quedó poco reflejado en los escritos de la época, por lo menos los investigados o en nuestra forma de acercarnos a ellos.

Como es sabido, en la edad media proliferan todo tipo de interpretaciones de textos sagrados, apócrifos o teológicos, lo que dio lugar a todo un bosque de alegorías, leyendas, tipos, antetipos, prototipos, arquetipos, símbolos, metáforas, etc., que se expresaron en obras literarias o artísticas. El libro que nos ocupa hace un excelente resumen de muchos de ellos por lo que resulta sumamente útil y ameno, tanto para el estudioso como para el mero aficionado. Muchos de estos escritos y obras plásticas tienen o se les puede encontrar un sentido simbólico. Pero si de lo que se trata es de exponer *el mensaje simbólicon del título, hay que decir cuál es este contenido simbólico de la imagen y no remitirlo a un mero valor metafórico, alegórico u otras analogías que no 
son simbólicas. Así, no solo la predicación del zorro a las gallinas del Roman de Renart no tiene valor simbólico sino que, por ejemplo, si se hubiera explicado porque el Paso del Mar Rojo es antitipo del bautismo de Cristo nos hubiera podido explicar también el sentido simbólico común de ambas narraciones. En lugar de esto, parece poner la tipologia medieval en el mismo nivel de las alegorías morales de los animales o de la descripción de simples costumbres y supersticiones.

Ello puede explicar que, cuando el autor, en la primera parte, resume las diversas teorías que otros autores han hecho sobre el simbolismo, de vez en cuando caiga en ciertas incoherencias explicativas, lo que denota, a mi juicio. que el autor repite lo que ha leido sin, muchas veces, captar su verdadero sentido. Ahora bien, este defecto no es exclusivo de Sebastián sino un hecho bastante común en personas que, como historiadores generales, del arte y de la literatu- ra, teólogos, etnólogos, etc., se ven obligados a manejar un material cuyo contenido simbólico, si bien reconocen, no acaban de captar. El simbolismo parece que quiere imponerse como una disciplina importante $o$ auxiliar en muchos campos relacionados con las ciencias humanas, pero su manejo por personas no especializadas o con poca sensibilidad para cl tema puede conducir a confusiones algunas veces más graves que su desconocimiento.

La inclusión de ejemplos valencianos de los siglos XIV y XV muestra que el autor estaba en estos campos más en su ámbito. También su manera de explicar la religiosidad medieval denota que la ideología del autor está más en sintonía con obras de arte más tardias. Pero su empeño por acercarnos al arte medieval es más que loable, ya que el libro es un resumen de la visión del mundo de la que emerge el arte cristiano anterior al Renacimiento.

\section{Maria Assumpta Garcia Renau}

\section{Abulafia, David}

A Mediterranean Emporium. The Catalan Kingdom of Majorca Cambridge: Cambridge University Press, 1994. XXIV, 295 p. Traducción en castellano: Un Emporio Mediterráneo

Barcelona: Omega, 1996

Por fin todos los investigadores del reino de Mallorca cuentan con una obra de referencia ineludible. Desde que Hillgart iniciara sus investigaciones sobre la Corona de Aragón y advirtiera sobre su sospechosa homogeneidad se produjo un cambio de perspectiva en los estudios sobre el Mediterránco medieval que tiene una de sus culminaciones en el libro que ahora presento. Nunca antes este reino habia sido situado con tanta precisión, estudiado desde el mismo prisma que se aplica al resto de los reinos que existian durante la edad media en la actual geografía española. El reino de Mallorca era un territorio heterogéneo que englobaba dos realidades diferentes: por un lado las islas, plenamente integradas en las rutas comerciales mediterráneas y atlánticas, que se caracterizan por su constante actividad comercial con el norte de África y por su continua aportación de infraestructura naval necesaria a otros para el desarrollo de la aventura mercantil. Por otro lado, los territorios continentales integrados en las rutas terrestres que enlazaban el norte de Europa con el Mediterráneo occidental y más comprometidos con el desarrollo de actividades manufactureras. 
El desarrollo de una nueva interpretación sobre el reino de Mallorca, tan desconocido, obliga a Abulafia a utilizar una cierta repetición enfática. Ciertamente el lector no se perderá durante la lectura, pues los argumentos principales reaparecen constantemente a lo largo del libro.

Abulafia divide su obra en tres partes, las cuales engloban cada una de ellas diversos capítulos. La primera, de cinco capítulos, es utilizada para presentar el escenario en el que tendrá lugar el drama que pretende narrarnos: el drama del fracaso del reino de Mallorca. ¿Cuáles son las causas de su desventura? ¿Porqué no uanscendió su existencia en la historiografia posterior? Todos estos interrogantes encuentran sus elaboraciones -histórica, juridica, historiográfica y también de interpretación - en esta primera parte.

En el capítulo primero, el ejercicio preliminar indispensable es situar correctamente al lector. Abulafia realiza un pequeño recorrido por las Islas Baleares desde el siglo vIu hasta su conquista definitiva por Jaime I en 1229 . Este viaje resulta necesario, debido a la habitual omisión de esta región en muchos compendios de historia de España. Recuerda el historiador que las Baleares fueron el último territorio en ser conquistado por los musulmanes - que las usarán como base permanente en sus incursiones de saqueo a las costas cristianas-, y que se vieron aisladas de la oleada almohade, prosperando como un importante enclave comercial. La conquista catalana tuvo como consecuencia un repartimiento feudal; una organización del espacio semejante a la desarrollada en los territorios cristianos de Tierra Santa, aunque los problemas aparecen $-y$ esto está ampliamente ejemplificado en los capítulos posteriores-, tras la muerte del Conquistador, cuyo ambiguo testamento obligaba al reino de Mallorca a usar la moneda de Barcelona y a regirse por los usatges. Se plantea entonces un interro- gante turbador: Es el reino de Mallorca un territorio independiente o sometido a la Corona de Aragón? Este será un problema que resurgirá a lo largo de toda la existencia del reino, y que encontramos también salpicando la obra en todo momento. Así, la economía isleña prosperó rápidamente y de forma inversamente proporcional a la capacidad de los miembros de la dinastía reinante para hacer frente a las presiones exteriores sobre todo aragonesas-. Sólo bajo Jaime III, el reino se decide a poner fin a esta ambigüedad (un rey no puede estar sometido a otro rey), encontrando entonces el final de su autonomía. Incorporado ya a la Corona de Aragón, el reino sufre las mismas incertidumbres que la península. Abufalia habla, de los siglos XIV y XV. Habla de la crisis. La ambigüedad del vocablo y las premisas, aún no resueltas, del debate Brenner, permiten a Abulafia evitar entrar directamente en el conflicto y pasar, de momento, al capítulo siguiente.

En el capitulo segundo se hace patente que esta obra viene a cubrir un hueco historiográfico. El reino de Mallorea el propio Abulafia lo expone de forma pormenorizada - ha recibido muy poca atención por parte de los historiadores. Ello, puede decirse, se debe a su corta duración. Sin embargo, para Abulafia, existen otros problemas: la excesiva concentración de los estudios en el reino de Castilla, la total dispersión de las fuentes (diseminadas entre varios archivos en diferentes geografias) y el hecho de que el reino de Mallorca englobe territorios que en la actualidad pertenecen a varios paises. Esta obra olvida, sin embargo, otras, como son el excesivo énfasis de los historiadores catalanes en presentar la crónica catalano-aragonesa como un entramado de acontecimientos que se desarrollan en un marco de harmonía entre las distintas ramas de la monarquía. Abulafia sabe quitarnos pronto esta venda de los ojos, al demostrar cómo el reino de Mallorca tuvo 
que ser conquistado en dos ocasiones por los soberanos aragoneses: la primera conquista bajo Jaime 1, en 1229. La segunda por Pedro IV de Aragón, que aprovechó los continuos intentos de la dinastía mallorquina por acercarse a Francia, para conquistar las islas.

Se nos ofrece seguidamente un resumen acerca del estado actual de las investigaciones sobre el reino de Mallorca, alertándonos sobre su extremado carácter localista, tanto en lo que a las islas se refiere como en los territorios continentales, en contraste con la insospechada riqueza de las fuentes del reino, muy numerosas. El capítulo $-y$ esto es una constante-acaba con otra de las claves del drama: la Mallorca medieval nunca pudo ser, en términos comerciales, un reino totalmente independiente.

El capítulo tercero explica cómo el reino catalán de Mallorca se movió siempre entre la ambigüedad: por una parte, estaba su prestigio como enclave comercial de primer orden; por otra, se le ha considerado siempre un reino gobernado por una dinastía torpe, incapaz de hacer valer sus derechos como soberanos independientes ante los reyes de Aragón. Pero hay otros problemas sobre los que Abulafia induce a reflexionar; Era el reino de Mallorca una dispersión de territorios o, por el contrario, estamos ante un estado fronterizo concebido como un plan? Sin duda, no podemos hablar aún de un estado: el reino nunca tuyo un ejército profesional al mando de la monarquía; jamás contó con un mecanismo de propaganda a su servicio eficazmente desarrollado (no existen crónicas autóctonas), que permitiera a sus ciudadanos una conciencia distintiva; no desplegó un sistema de fiscalización cficaz, pues, de hecho, nunca estuvo claro si los catalanes debian pagar los impuestos comerciales. Por otra parte la situación de Montpellier era muy ambigua. Todas estas razones han propiciado que se hable de un "feudum honoratum sine omni servicion, de un feudo al servicio de los condes de Barcelona. La clave: el reino catalán de Mallorca sufría un adesdoblamiento de personalidad».

Los capitulos siguientes - cuarto y quinto- tienen una estructura unitaria. Abulafia propone un ejercicio de perspectiva: si el reino de Mallorca es, en definitiva, uno de los reinos de la España peninsular, jporqué no observarlo como lo hubieran hecho los gigantes de la historiografia de la edad media en España? ¿Porqué no ver el reino de Mallorca bajo el prisma propuesto por Américo Castro, incidiendo sobre la coexistencia de las tres religiones (musulmanes, judíos y cristianos)? Asi reaparece en la escena de la historia el mito de la relación entre estas religiones universales.

En el capítulo cuarto se analiza la posición de los musulmanes en esta convivencia. El lector tendrá así notícia de que la mayor parte de los que vivian en las islas en el siglo XIII no eran de origen balear: los sarracenos autóctonos fueron diezmados de tal manera durante la conquista que los colonizadores se vieron obligados a importar esclavos y mano de obra del reino de Valencia. La población musulmana, además, apenas aparece en la documentación relativa al comercio. Consta, también, que muchos de ellos intentaron huir de la isla. Abulafia se ve en la obligación de confesar que, aunque la corona no estableciera nunca una política antimusulmana, se creó una cierta atmósfera hostil. Era necesario que Mallorca, ese emporio mediterráneo, limpiara su ancigua imagen de enclave musuimán para no ahuyentar a los ricos mercaderes italianos en su deseo de establecerse en la isla. Pero, según se desprende de la lectura del libro, Mallorca no fuc la única geografia del reino que se vio envuelta en esta atmósfera hostil: también la población sarracena de Menorca, tras su conquista en 1287 , fue condenada a la esclavitud, alimentando el ya floreciente mercado de esclavos mallorquín. 
En el quinto capítulo nuestro autor se siente más cómodo. No en vano ha dedicado gran parte de su vida y de sus investigaciones al problema de las comunidades judías. Esta erudición le permite partir de la base de que dichas comunidades de Mallorca tenian vínculos familiares con la península Ibérica, el sur de Francia y el Magreb, para desglosar finalmente el capítulo en dos grandes apartados: la reclusión de los judios en el Cally el papel de los mismos en las ciudades de Perpiñán y Montpellier en la concesión de créditos. Estas comunidades judias fueron obligadas a permanecer en los Call desde 1229 hasta 1435 debido a que Mallorca era un territorio de frontera. La existencia de dichas comunidades en las islas se justificaba por el enorme interés financiero que tenían para los conquistadores. A pesar de todo, "Mallorca became something of a haven for foreign Jews\%, pues permitía estrechar lazos comerciales con todos los puertos del Mediterráneo occidental y además los judíos estaban vinculados a todas las esferas comerciales de la isla. También la situación de los judíos del sur de Francia es analizada por Abulafia y lo primero que se pone de manifiesto es la dificultad que supone el estudio de estas comunidades. Pero, según se deduce de su investigación, la participación de los judíos en las operaciones comerciales se limitaba a la financiación de las mismas. Todo ello permite a Abulafia concluir que el reino de Mallorca es el lugar paradigmático del fracaso de la convivencia de las tres religiones. ¿Realidad histórica o espejismo historiográfico?

La segunda parte del libro, compuesta de seis capítulos (del quinto al onceavo), se inicia en el capítulo sexto y en ella se aborda en profundidad toda la problemática referente al comercio, analizada en tres planos: la situación antes de la conquista (hasta 1229), durante el proceso de gestación del reino $y$, finalmente, tras su reincorporación a la Corona de
Aragón. Según puede leerse, los vínculos comerciales entre Mallorca y Barcelona eran ya estrechos antes de 1229 , aunque obviamente se intensificaron a raíz de la conquista, propiciando, en los años 40 del siglo XIII, la aparición de una élite comercial en proceso de formación en la isla formada por comerciantes toscanos y entre los que el elemento catalán no parece constituir un factor de gran peso. La conquista, realizada sin la ayuda de las flotas italianas, supuso un punto de inflexión en la lucha que mantenian las ciudades mediterráneas por la hegemonía marítima. Sin embargo, para ascgurar la isla, Jaime I opta por ampliar los privilegios a las crecientes elites italianas de la isla. A medida que la ciudad se desarrollaba, se iba haciendo más dependiente de la importación de grano, pues los intentos por potenciar la agricultura balear fracasaron debido a la cercanía de Sicilia, el principal productor agrícola del Mediterráneo. El capital y la iniciativa de las comunidades judias, al parecer favorecidas inicialmente por la conquista cristiana, tuvieron también una notable incidencia en el comercio balear. Mallorca fue, sobre todo, un lugar de paso, una escala necesaria en las rutas que conectaban las costas italianas con el levante de la peninsula Ibérica, el norte de África y, posteriormente, con las ciudades europeas del Atlántico. El Magreb parece ser, sin embargo, el destino comercial por excelencia (Túnez, Alger, Ceuta...). El papel de los territorios continentales - en especial Montpellier- es clave para entender las rutas de los mercados europeos al permitir la entrada de artículos de lujo procedentes de Mallorca, hacia los mercados continentales.

El séptimo capirulo se detiene en la situación del comercio mallorquín durante el turbulento período de las vísperas sicilianas. Sin duda el enfrentamiento entre los Ánjou de Francia y la casa condal de Barcelona perturbó las rutas del comercio balear, sobre todo desde el ins- 
tante en el que el rey de Mallorca Jaime II creyó que una alianza en contra de los catalano-aragoneses le permitiría, de una vez. por todas, el fin de su supuesta dependencia de dicha Corona. Este enfrentamiento abierto obligó a la ruptura con Cataluna, dificultando la importación de grano, en manos de los catalanes peninsulares. El comercio de Mallorca se vio, por lo tanto, obligado a reorientar sus puntos de destino y la dinámica de su red comercial, más limitada geográficamente tanto por la conflictividad de los destinos tradicionalmente peninsulares como por la obligación de los mercaderes mallorquines de no aventurarse más de unas semanas en cada partida. Un análisis detallado de las fuentes de la época (en especial del Llibre de Llicencies de 1284) permite a Abulafia replantear algunos mitos historiográficos como el de la escasez de navegación en los meses de invierno (que desde Braudel era una premisa incuestionable) y que no es evidenciable en la Mallorca de 1284. Se aprecia, por otra parte, una intensificación de los vínculos comerciales con los territorios musulmanes (en especial con Sevilla y el Magreb, siendo los puertos más próximos los más visitados), acompañada del creciente interés de la monarquía por establecer cónsules en los puertos de destino de sus barcos. Dichos cónsules estaban en continuo litigio con sus homónimos catalanes. No obstante la fragilidad del reino de Mallorca se puso pronto de manifiesto y Jaime II acabaría perdiendo las Baleares. A dos ańos del final de la guerra de las Vísperas y tras una breve experiencia de hegemonía catalana uit was not clear, around 1300 , what benefit the restoration for Majorcan rule over the Balearics would bring the island's merchantsi.

En el capítulo octavo el historiador analiza la evolución del reino durante la primera mitad del siglo xIV. Para él una cosa está clara: la monarquía mallorquina no estaba capacitada para convertir el reino en un estado autónomo independiente de las potencias exteriores. A cambio, intentó desarrollar una ambiciosa política económica que incluía fundación de ciudades, intensificación de sus redes comerciales con el norte de África, creación de consulados en puertos extranjeros, construcción de una flota comercial y acunación de moneda propia. Todas estas medidas constituyen las bases de un imaginario político desarrollado a instancias de la monarquía que trataba, además, de que el reino fuese, si no autosuficiente, sí menos dependiente de la importación de cereal y materias primas, pues la economía del reino, tanto en las islas como en los territorios continentales, se encontraba dominada por el comercio exterior. La mejora de las infraestructuras portuarias en las costas francesas del Mediterráneo provocó una forzada desviación de las rutas comerciales hacia estos nuevos canales de redistribución, produciendo graves consecuencias en la economía del reino de Mallorca.

El capitulo noveno de esta obra recorre las dos últimas décadas del reino independiente de Mallorca. Las fuentes documentales utilizadas por Abulafia para la exposición de este periodo se centran en los registros de ancoratge (impuesto que gravaba los barcos que llegaban a Ciudad de Mallorca). Sin duda la tipología de las fuentes ha determinado los resultados expositivos, pues apenas pueden inferirse las rutas que seguían los barcos que arribaban a puerto. Pero el análisis de su procedencia permite a Abulafia subrayar la importancia de los vínculos comerciales con los puertos atlánticos. Las islas Baleares compartían su papel intermediario en las rutas comerciales con los territorios continentales del reino de Mallorca. Del triángulo formado por el Rosellón, la Cerdaña y el Conflent, Perpiñán, centro de redistribución de los paños flamencos transportados al sur por via terrestre, era la ciudad más importante. Aparece entonces el contraste entre los 
territorios continentales y las islas: éstas florecian como centro comercial, mientras que aquellos tenian un marcado perfil industrial. La privilegiada situación geográfica de todos los territorios del reino en las rutas que unian la Europa mediterránea y septentrional con África, Italia y el levante peninsular hispano fueron, sin duda, claves para el éxito económico del reino.

El décimo capítulo lo dedica el autor a tratar un tema muy poco estudiado: el papel del reino de Mallorca en las rutas mercantes del Atlántico. Abulafia plantea cómo la navegación más allá del estrecho de Gibraltar exigía la resolución de algunos problemas de diversa indole. En primer lugar, era necesario cristianizar el estrecho (conquista de Murcia, 1265) para permitir la libre circulación de barcos hacia las ciudades atlánticas (- ¿ej avance de las conquistas cristianas fue paralelo a los intereses económicos y comerciales?-). Pero los avances debían ser también tecnológicos, pues el océano Atlántico no es un mar tranquilo. La consecución de todos estos objetivos permitió que, a finales del siglo XIII, los hombres de negocios mallorquines hubiesen establecido relaciones, a través de los itinerarios marítimos atlánticos, con Inglaterra y Flandes, donde compraban lana que transportaban a las ciudades manufactureras del Mediterráneo. Especialmente interesante en este capítulo es el ataque a las tesis de Roberto López acerca de la rivalidad entre Génova y Mallorca en el comercio con Inglaterra. La cuestión es replanteada por Abulafia quien, a la luz de nuevas fuentes, afirma que ambas ciudades protagonizaron, en realidad, la apertura y explotación de las rutas atlánticas. El viaje por estas aguas no estaba únicamente expuesto a los peligros naturales: la piratería, consentida en algunos casos, era uno de los mayores peligros para los barcos de los comerciantes mediterráneos. Importante es seńalar aquí, y así lo hace Abulafia, el elevado conocimiento que los mallorquines tenían de las costas de la Europa atlántica y del noroeste de África, conocimientos que plasmaron en multitud de mapas portulanos, caros y frágiles, que producian para los miembros de las monarquías europeas y para ricos mercaderes.

Con el capitulo onceavo finaliza la segunda parte de esta investigación. En ella Abulafia sintetiza la evolución de los territorios del reino de Mallorca tras su reincorporación a la Corona de Aragón, reincorporación que coincidió con una transformación, con una reorientación de la cconomía del reino como respuesta adaptativa a los problemas que planteaban la aparición de la peste negra y el consecuente desequilibrio en el circuito de la oferta y la demanda. La escasez de mano de obra, según Abulafia, lanzó a Europa hacia la ganadería, cuyos recursos fueron explotados de manera sistemática. Las islas reaccionarán desarrollando, además, una cierta industria textil. Gran importancia tiene en este momento el interés comercial que despierta la isla en la persona de Francesco di Marco Datini, cuyo ingente archivo es la mejor fuente histórica para el conocimiento de este período.

A grandes rasgos parece ser que los conracros mercanriles se mantuvieron en estos momentos, aunque descendientes en las rutas practicadas de forma habitual hasta entonces, pero intensificados entre Mallorca y los puertos catalanes más cercanos, como Barcelona.

Como conclusión Abulafia nos ofrece la última clave para la comprensión del complejo problema que trataba de explicarnos en las páginas anteriores: «The Catalan kingdom of Majorca was a political failuren.

La tercera y última parte de este libro comprende los dos apéndices. Sólo en ellos el público poco especializado puede encontrarse algo desconcertado. Mallorca and Sardinia 1267-1343 [Apéndice 1] y The Montpellier inquest, 1338-1339[Apéndice 2] están, en efecto, tratados de manera más 
rigurosa, aportando algunas transcripciones documentales que ayudan a equilibrar el conjunto de la investigación.

Este libro debe ser un punto de referencia obligado, un punto de partida necesario para todos los estudios posteriores sobre el reino de Mallorca. Además de contar con un soporte bibliográfico y documental tremendamente sólido, aporta una observación novedosa del reino trabajado aquí desde el principio, al mismo nivel que otros reinos del Mediterráneo medieval. La novedad se combina con el mantenimiento de métodos clásicos de acercamiento a algunos temas. El estudio de la población y de las relaciones que se establecen entre ellos (la vida, en definitiva) desde el prisma de las convivencias de las tres religiones comienza a reclamar, a finales de los 90 , un giro de perspectiva; el desarrollo de una nueva metodología que acoja las constantes aportaciones bibliográficas aparece como un ejercicio necesario. Sin embargo esta es una obra importante, que se hace imprescindible para una seria contextualización del mediterráneo en los siglos XIII, XIV y XV.

\section{F.J. Rodriguez-Bernal}

\section{FABREGA I Grau, Ángel}

Diplomatari de la Catedral de Barcelona, vol. 1. Documents dels anys 844-1000 Barcelona: Arxiu Capitular de la Catedral de Barcelona, 1995. 706 p.

El fondo documental del Arxiu Capitular de la Catedral de Barcelona tiene su origen en el segundo cuarto del s. IX, aunque no es hasta mediados del s. XIII cuando toda la colección documental se ordenó para formar el primer archivo de la catedral. El documento original más antiguo que se conserva en el archivo data del periodo $875 / 877$, producido en la cancillería de los reyes carolingios, es la carta de saludo, agradecimiento, estímulo y envio de ayuda coonómica por Carlos el Calvo a los barceloneses, aunque el más antiguo es el documento número uno copiado en el Cartoral datado el año 844.

El presente volumen corresponde al primero de un proyecto de investigación que pretende la publicación sistemática de la documentación medieval del archivo catedralicio. Esta publicación plasma, por fin, el sueño de muchos investigadores que se habian planteado la necesidad de publicar dichos fondos, $y$ en especial los volúmenes del cartulario de la catedral, conocido como Libri Antiquitatum. Los impulsores del proyecto determinaron el término ad quem al año 1260, para que de este modo la fecha coincidiese con la del último documento datado del Cartoral.

El proyecto, fraccionado en diversas etapas, tiene como objeto, en una primera fase ya realizada, el estudio y edición de los pergaminos originales y las copias, de los siglos $\mathrm{x}$ y $\mathrm{x}$, un total de 350 documentos. La segunda etapa, ya iniciada, recogerá los documentos del siglo $\mathrm{XI}$, unos dos mil. Las siguientes etapas recogerán otros cuatro mil documentos, hasta llegar al año 1260. El conjunto del proyecto prevé el estudio y publicación de más de seis mil documentos del Arxiu de la Catedral de Barcelona.

En el presente volumen destacan dos partes bien diferenciadas, una primera de estudios (p. 3-179) que se inicia con una introducción general de todo el diplomatario y una segunda con la edición de los documentos. Angel Fabrega realiza en el primer capítulo un detallado recorrido por la historia del archivo, desde sus orígenes hasta nuestros días, destacando el importante papel que jugaron archiveros como Mn. Francesc Tarafa en el s. XVI, O 
el premostratense Jaume Caresmar en el s. XVIII, y ya en nuestro siglo Mn. Josep Mas, autor de los trece volúmenes de la colección «Notes Històriques del Bisbat de Barcelona».

La descripción externa e interna de los Libri Antiquitatum es el eje central del segundo capírulo. El Cartoral de la caredral, escrito a mediados del s. XuII, es la joya documental del archivo capitular, $y$ la importancia de estos cuatro volúmenes hace que se les dedique una parte destacada en el cstudio preliminar (p. 59-165). El autor lleva a cabo un pormenorizado análisis codicológico de los diferentes volúmenes.

El tercer capítulo es la introducción al volumen I del diplomatario (años 8441000). A través de un análisis del continente y del contenido de las series documentales nos introducimos en el conocimiento del corpus documental formado por los pergaminos y los documentos copiados en los Libri Antiquitatum. Merece una especial atención la parte dedicada a la tipología de los documentos, destacando la documentación real y condal, los actos judiciales, las cartas de franquicia, las permutas, los testamentos y las ventas. La mayor parte de la documentación ( 323 doc.) son instrumentos otorgados por personas privadas pertenecientes a todos los estamentos de la sociedad civil y eclesiástica de los siglos IX y X.

Los estudios de análisis cronológico, tanto del estudio general como de la introducción al primer volumen, corren a cargo de Josep Baucells i Reig, quien dedica un especial interés al reinado de los reyes francos $y$ sus incidencias cronológi- cas. El estudio cronológico de los documentos va acompañado de una serie de cuadros cronológicos que abarcan del S, IX al XIII que complementa el estudio, resaltando la serie de reyes francos, la cronología de los condes de Barcelona y de los reyes catalanoaragoneses, los obispos de Barcelona y la cronología de los papas y antipapas.

El cuarto capitulo tiene por objeto establecer la normativa general de edición de los textos, señalando los criterios seguidos en la grafía de las palabras, el uso de mayúsculas y minúsculas, la puntuación, los signos utilizados y las abreviaturas.

La segunda parte de la obra corresponde a la edición crítica de los textos documentales (p, 181-591), un corpus documental que se convertirá en centro de referencia obligada para el estudio de la alta edad media catalana, y de manera especial para Barcelona y su área de influencia.

La obra finaliza con una serie de indices de interés y utilidad para los investigadores encontraremos indices crono lógico, antroponímico, toponímico, de escribanos y notarios y un índice general.

Sin lugar a dudas nos encontramos ante una obra de especial interés, largamente esperada, que, en su conjunto, nos brinda la oportunidad de conocer mejor el patrimonio documental catalán y, en particular, la documentación anterior al año 1000 . Se hace necesario que vean la luz obras de este tipo, que cada vez más dispongamos, en nuestras bibliotecas, de fondos documentales editados.

\section{Juan José Cortés}

SANCHEZ MARTÍNEZ, Manuel (compilador)

Estudios sobre renta, fiscalidad y finanzas en la Cataluña Bajomedieval Barcelona: CSIC; Institución Milà y Fontanals, 1993.510 p.

Ens trobem amb un magnífic primer resultat d'un projecte d'investigació finançat per la DGICYT, que agrupa destacats historiadors de l'edat mitjana catalana. 
Aquesta és la primera consideració que cal fer: l'estudi de temes tan complexos per la temàtica i la documentació no es pot fer sinó és en equip i cercant el finançament adequat. Els projectes d'investigació palesen la seva utilitat en publicacions com aquesta.

El titol és prou clar per adonar-se de l'àmplia temàtica abordada dins d'un tema monogràfic: la forma d'obtenció dels recursos reials i senyorials $i$ la problematica que suscita.

Dels catorze treballs compilats per Manuel Sánchez, l'investigador responsable del projecte, es poden advertir clarament dues línies principals d'investigació: la utilització dels capbreus com a font essencial en l'estudi de les rendes feudals i la fiscalitat, l'altre element essencial en els recursos feudals tant per part de la monarquia com dels municipis o de les institucions eclesiàstiques.

Els estudis de Pere Benito i Pascual Ortega, a més de delimitar la cronologia de tot el recull, representen clarament una introducció i un enllaç amb els segles moderns que en aquesta temàtica tantes semblances tenen amb la baixa edat mitjana. En efecte, Benito tracta dels orígens de la pràctica de capbrevació mitjançant l'analisi formal de 107 textos anteriors a 1250 qualificats de formes diverses: "breve", "memoratio", "capud breve"; però que innegablement, com demostra, són l'origen dels capbreus baixmedievals i moderns, i precisament d'aquests darrers se n'ocupa el treball d'Ortega, una molt acurada i rigorosa aproximació metodològica a aquest tipus documental generalitzar des de les darreries del segle $\mathrm{xv}$. Aprofitament exhaustiu d'un capbreu es mostra en l'aportació del mateix Manuel Sánchez que, a través del capbreu de les rendes reials dels anys $1440-44$, aprofundeix, i de quina manera, en l'anàlisi del domini reial.

En el camp de la fiscalitat també se'ns mostren les possibilitats d'utilització de fonts documentals en el treball de
Morelló sobre els Llibres d'estimes de Reus.

Cronològicament, un dels primers treballs que trobem és el de Salrach, el qual aprofitant la informació que ens dóna un inventari dels dominis, rendes i drets dels comtats de Barcelona, Girona, Besalú i Cerdanya de 1151-1152 publicat pel professor Bisson, porta a terme un minuciós estudi de la geografia de les possessions comtals, de la seva administració i dels elements, rendes i serveis que se'n deriven. A destacar, entre moltes altres interessants informacions, la cronologia d'alguns dels mals usos: així la cugúcia està documentada el 1058; l'arsina, el 1071, i l'eixòrquia, el 1068. Aquesta darrera part del treball, la més interessant, constitucix un aprofundiment a la tipologia de rendes i de serveis feudals existents a la Catalunya Vella a mitjan del segle XII.

Una mostra d'un diferent aproficament dels capbreus és el treball de Silvia Gassiot: "Herència i mercat de la terra: l'accés a la propietat al domini de Cervelló segons el capbreu de 1374-1377n. Fonamentalment l'estudi se centra en els mecanismes de la transmissió dels béns palesats en el document estudiat distingint encertadament la transmissió hereditària de la que té per base una compravenda o alguns dels contractes agraris.

Montagut aborda l'inici de l'estudi sobre la recepció del dret feudal comú a Catalunya, que lògicament té molt a veure $\mathrm{amb}$ el règim de les tinences feudals. La publicació d'un document inèdit en el qual es recullen els "torts" fets a la monarquia clou aquest interessant treball que massa modestament l'autor subtitula com a Notas para su estudio, referint-se a l'esmentada recepció.

Dues interessants aproximacions al tema de la fiscalitat, pel que fa al dret de cena de presència i al bovatge, són obra de Marina Miquel i Tomàs López, i són clara mostra de les possibilitats que la rica documentació conservada ens ofereix sobre això. 
En l'aspecte de les rendes reials es presenten les aportacions de Flocel Sabaté sobre les rendes de les castlanies, estudi molt extens i documentat, supera les quatre-centes notes, i que juntament amb l'article del compilador del volum, M. Sánchez esmentat abans, em semblen els d'una major qualitat i rigor científics. També voldria destacar el treball de Pere Ortí sobre la formació i l'evolució de l'explotació de les rendes dels molins reials del Ree Comtal, temàtica fins ara només tractada molt per sobre per la historiografia.

També el camp de les rendes derivades de mercats rurals troba el seu lloc en aquest recull gracies a l'estudi de Mercè Aventín, en el qual demostra la doble finalitat del mercat de rendes: la resolució de les necessitats econòmiques i la garantia de la salvació eterna, estudiant el cas de Vilamajor.

La fiscalitat eclesiàstica és objecte d'un documentat estudi del professor Prim Bertran, que empra els registres de la Secció del Mestre Racional de l'ACA, que ofereix publicats en apèndix. La quantificació de la decima apostolica per bisbats ens mostra novament les possibilitats que la documentació existent ens proporciona.

Un breu, però dens, estudi de Guilleré sobre les finances de la Corona d'Aragó a l'inici del segle XTV ens dóna clara prova de l'aprofitament de la documentació i clou aquestes magnifiques $i$ completes aportacions que ens ofereix aquest volum compilat per M. Sánchez.

\section{Antoni M. Udina i Abelló}

\section{SÁNCHEZ MARTÍNEZ, Manuel}

El naixement de la fiscalitat d'Estat a Catalunya (segles XII-XIV)

Vic: Eumo; Universitat de Girona, 1995.147 p.

L'especializzació de l'investigador Sánchez Martínez en temes de fiscalitat, palesa des de fa ja alguns anys, ha donat com a fruit aquesta condensada $i$ al mateix temps detallada síntesi d'un dels aspectes més característics de l'organizació de les monarquies feudals: la fiscalitat d'Estat. L'estudi se centra a Catalunya, que encara que des de 1137 forma un unitat política amb el regne d'Aragó, és clar que, com en molts altres camps, en la fiscalitat té una evolució diferenciada de la d'Aragó, primer, i de la resta de regnes i territoris annexionats més tard a la Corona d'Aragó. Parteix cronologicament de les primeres manifestacions del que anomena adequadament fiscalitat extraordinaria, en l'època del comte-príncep Ramon Berenguer IV i concretament fent esment de l'inventari del 1151-52 i que acaba el 1365, quan arran de la consolidació del General de Catalunya com a institució, "Les generalitats van convertirse en un impost practicament estable.... (p. 134).
Com és ben sabut, l'itinerari que des de mitjan del segle XII a mitjan del XIV porta a l'establiment definitiu de la fiscalitat d'Estat té estreta relació amb l'evolució política $\mathrm{i}$ les necessitats financeres que l'expansió mediterrània, primer, i sobretot, les campanyes militars després, plantejaven. Aixó ha estat molt ben copsat per l'autor al llarg dels set capitols en què ha dividit la seva obra.

Especial interès, segons la meva opinió, tenen les referències a les fonts documentals escaients per a l'estudi que ens proposa Manuel Sánchez. Ja en el primer capitol se'ns dóna «Una ullada breu a les principals fonts documentals», títol del capitol (p. 19), ullada ben indicativa de la línia de recerca de l'autor i que, encara que com ell mateix diu, no és exhaustiva, permetra emprendre l'estudi de la fiscalitat catalana a altres historiadors. En tractar, en el capítol quart, del primer quart del segle XIII dedica també un apartat a linterès i a les limitacions de les fonts per 
a l'estudi del patrimoni reial (p. 67-71) que denoten un intens i profitós treball sobre el tema que l'ocupa i del qual, com queda dit, tenim ací una evident manifestació. Vull remarcar molt especialment aquest rigor documental $\mathrm{i}$ la transparència en donar a conèixer en detall la ubicació de la documentació estudiada, tot i tractant-se, com diu el mateix autor, d'una síntesi d'alta divulgació.

El llibre destaca a més a més per la seva claredat expositiva, des del moment que relaciona amb precisió els principals fets polítics i militars amb el procés formatiu de la que ell, amb plena justificació (p. 10-11), anomena fiscalitat d'Estat.

El perquè considera que fins a la segona meitat del segle XIV no es pot parlar de fiscalitat d'Estat roman palès en les pàgines introductòries: d'una banda a les darreries del segle XIII i primera meitat del XIV els impostos votars en Corts afectaven solament el braç reial o de les ciutats. A partir de 1360 també els braços militar i eclesiàstic es veuran obligats al pagament dels tributs fiscals votars en la Cort: la proferta o donatiu, que a partir del 1350 representarà la gran part dels recursos financers de la Corona. Un segon argument de l'autor per situar en l'epoca citada la definitiva consolidació de la fiscalitat és el seu "caràcter regular i permanent, sense que depengui ja de les contingències bel-liques del periode anteriors (p. 11).

D'altra banda, la complexitat del tema és ben evident. Només llegint la sbaterian de preguntes plantejades per Henneman en el seu estudi sobre el finançament de la guerra en la França del segle XIV i que recull Sánchez, hom es pot fer una clara idea de la problemàrica que la recerca sobre la fiscalitat en qualsevol regne medieval suscita.

El procés formatiu o naixement, com es titula l'obra, d'aquesta fiscalitat d'Estat bascula contínuament entre els recursos que genera el patrimoni reial $i$ les apel-lacions a la fiscalitat extraordinària, quan, per dispendis del patrimoni, cas del regnat de Pere el Catòlic, o per necessitats excepcionals, que esdevenen corrents, cas de les guerres amb Gènova, Sardenya, Castella, etc., els recursos patrimonials no són suficients.

L'estreta relació de Corts i municipis catalans és una altra de les característiques que es desprenen d'aquest treball, des de moment que mostren clarament un aspecte que sovint ignora l'historiador de les institucions.

Els precisos i complets aclariments bibliogràfics succintament comentats per capitols clouen aquest treball, el qual, malgrat la qualificació que fa Manuel Sánchez de pàgines un xic prematures, crec que ens trobem davant d'una obra que ens era del tot imprescindible i que obre el cami cap a la recerca de l'evolució d'aquesta fiscalitat en la Catalunya dels darrers segles medievals, camí, que em consta, continua obrint, trepitjant i avançant Manuel Sánchez i el seu equip de treball.

Antoni M. Udina i Abello

SCIASCIA, Laura

Le donne e $i$ Cavalier, gli affani $i$ gli agi. Famiglia e potere in Sicilia tra XII eXIV secolo

Messina: Sicania, 1988

Pergamene siciliane dell'Archivio della Corona d'Anagona (1188-1347)

Palermo: Società Siciliana per la Storia Patria, 1994.

Dues aportacions singulars de la doctora Laura Sciascia, de l'asidua recercadora de documentació siciliana a l'Arxiu de la
Corona d'Aragó des de fa uns quants anys. Realment ella completa els seus estudis propis del seu país sobre els docu- 
ments de la lloctinència de Frederic d'Aragó (Palerm, 1972) i sis anys més tard el Volum d'Acta Curie Felicis Urbis Panormi.

Ara ens ofereix un volum que recull els pergamins del nostre Arxiu Reial des del 1188 al 1347 . Es tracta de documentació més aviat privada i que ja havia conegut Carini respecte a la dels regnats des de Pere II a Jaume II, mentre que els documents del temps de Pere III havien estat citats per Giuffrida (d'aquests pergamins, n'havia editat 117 al Cartulario Alagona).

Encara que es dóna la data del 1188 . de pergamins anteriors a Jaume I n'hi ha solament dos. A partir del número 3 ja són des del regnat d'aquest rei, el Conqueridor. El nombre total de depergamins transcrits i degudament "regetats" arriba als 121, corresponents a l'any 1347.

El conjunt dels documents ofereix un gran interès per a l'estudi de la noblesa siciliana, i la relació amb els nostres reis és més aviat per incloure els regnats esmentats (també de Jaume II, els Alfons i sobretot Pere el Cerimoniós) que no pas per veure-hi la relació política d'aquests nobles amb la monarquia. Sobresurten, però, alguns pergamins atorgats pels mateixos sobirans catalanoaragonesos.

L'edició és molt correcta: cada document va precedit per la data, la signatura, etc., i conté un ampli resum. Hi ha a més nou làmines que reprodueixen signatures de jutges $i$ de nobles, en un nombre bastant considerable. Uns índexs, a les darreres planes, que amb cura recullen onomàstics i topònims.

L'altra publicació de Laura Sciascia és un estudi familiar orientat, però, des del punt de vista de la relació entre familia i poder; el seu estudi va dels anys seixanta del segle XII, des del rei Guillem II, fins a la segona meitat del XIV, a l'època de Frederic IV. En conjunt estudia els esdeveniments de la Sicília a partir de cine famílies: els Abbate, Fimetta, Scordia, Incisa, Centorbi i Rosso.

Dedica quinze planes a distints arbres genealògics d'unes serze families. Inclou un bon index de noms i de llocs, en què es recull especialment les cites de les esmentades cinc famílies; cal remarcar que la família Moncada (escrit sense la $t$ després de la ena) hi ocupa un lloc molt important.

\section{Frederic Udina i Martorell}

\section{ALTTSENT, Agusti}

\section{Diplomatari de Santa Maria de Poblet (960-1177). Vol. I}

Barcelona: Abadia de Poblet; Generalitat de Catalunya, 1995.

Certament que la historiografia catalana es troba en un moment de plena satisfacció, ja que en molts pocs anys s'ha completat un aspecte de la història medieval: el de les fonts documentals. En aquest aspecte estàvem en una situació de retard.

Des del 1938, en què es va publicar el Cartulari de Poblet, gràcies a l'esforç de Pons i Marqués, vàrem haver de passar a la dècada dels quaranta, anys, per cert, de grans dificultats econòmiques; i malgrat això, l'Escuela de Estudios Medievales que tenia la seva seu a l'Arxiu de la
Corona d'Aragó, dirigida per Martínez Ferrando, treia a la llum dos diplomataris de gran volada: els dos volums del Liber Feudorum Maior, obra de Mn. Francesc Miquel i Rossell i, al cap de poc temps, el Cartulari del Monestir de Sant Cugat, en tres volums. Aquests densos llibres foren publicats gràcies a l'esforç de Mn. Josep Rius i també de l'Escola del Consell d'Investigacions Cientifiques.

Després sortia El Llibre Blanch de Santes Creus, també obra de l'esmentada Escuela i del també citat Consejo Superior 
de Investigaciones; aquest diplomatari el vàrem publicar l'any 1947. I tot just començada l'altra dècada, la nostra tesi doctoral El Archivo condal de Barcelona en los siglos $D X-X$. Estudio critico de sus fondos veia la llum a Barcelona, el 1951. L'esforç de l'esmentada Escuela de Estudios Medievales fou enorme: la cultura catalana podia estar orgullosa d'haverla dotada de set volums, que contenien quatre importants diplomataris, tot vencent les grans dificultats econòmiques del primer decenni després de la revolució i de la guerra de 1936-1939.

Però ara, a la dècada dels noranta - després de més de quaranta anyshan aparegut ni més ni menys que quatre diplomataris, $i$, per cert, d'origen eclesiàstic: ens referim a la documentació vigatana, a la gironina, a la barcelonina i a la populetana. Per això dèiem que la historiografia catalana, respecte a les fonts, estava d'enhorabona amb l'aparició de noves fonts documentals.

La primera a publicar-se fou la de l'esforçat treball de Mn. Eduard Junyent, canonge i historiador de Vic, amb el Diplomatari de l'Abat Oliba, editat per l'Institut d'Estudis Catalans. Un altre canonge, ara de l'Església de Girona, el Dr. Marqués, treia a la llum el Cartulari de Carlemany, i, el 1993 el pare Agustí Altisent donava a la impremta el Diplomatari de Santa Maria de Poblet, aparegut el 1955, i del qual parlarem expressament de seguida. El mateix any, una altra autoritat eclesiàstica, ara de Barcelona, el Dr. Fàbrega, editava el volum primer del Diplomatari de la Catedral de Barcelona, (la recensió del qual apareix també en unes altres planes d'aquesta revista).

Les nostres primeres paraules sobre aquest Diplomatari van adreçades al seu autor, el P. Agustí Altisent, OC., que des de fa més de vint anys s'ha preocupat perquè aquest monument paleograficodiplomàtic pogués sortir a la llum. Pel fet de pertànyer a la Germandat de Santa
Maria de Poblet podem testimoniar les vegades que s'ha parlat a les reunions de la Junta Directiva d'aquest cartulari, tot encaminant la seva impressió $\mathrm{i}$ insistint en el fer que calia fer-ne una edició modèlica, com ha estat. Ja en temps de l'abat Garreta, opinà que calia planejar una edició no solament amb el material del cartulari gran de Poblet, que està a l'Archivo Histórico Nacional de Madrid (com havia pensat l'esmentat abat), sinó que era necessari reunir tota la documentació i barrejar, per tant, el contingut dels dos cartularis (el que acabem d'esmentar i l'editat per IIEC, a què ja hem fet referència).

Cercant col-laboracions que bé s'esmenten en la introducció que ens dedica el P. Altisent, es va poder (a poc a poc), que es transcrivissin els microfilms de què disposava $\mathrm{i}$ després a base de fotografies o de fotocòpies: la tasca ha estat ingent, dificil i minuciosa; propia, com tantes vegades es diu, de monjos benedictins (al capdavall, ho és el cistercenc Altisent). La cura en la transcripció i en l'edició hi és ben notòria.

El volum que comentem és presentat pel conseller de Cultura de la Generalitat i per l'abat Maur Esteve, el qual sempre s' ha interessat per la publicació d'aquesta joia històrica i que a la primeria havia comptat amb l'ajut de la ja esmentada Germandat de Poblet.

A la introducció que segueix, el P. Altisent explica com han anat passant els anys des que l'esmentat abat Garreta volia començar amb la publicació del cartulari gran, i agraeix a tots els col-laboradors que s'hi citen, a més hi parla de la feina de direcció, tasca que sempre ha desenvolupat malgrat les ocupacions conventuals d'un monjo a més de les obligacions a la Delegació a Tarragona de la Universitat de Barcelona, com a professor d'Història medieval; el P. Altisent, a més, rreballà en una història de Poblet, molt ben extractada. Alguns altres monjos que l'ajudaren foren els pares 
Saladrigas i Tulla, sempre entusiastes del projecte.

El "corpus» editat reuneix ni més ni menys que 600 documents, procedents bàsicament de tres fonts: els dos cartularis, el gran i el publicat ja, i la documentació solta. Aquest conjunt de documents comprèn des de l'any 960 fins al $1177 \mathrm{i}$ constitueix, dones, el primer volum de la sèrie, no pas curta, des del moment que inclou uns quants segles de la historia de Poblet.

Cada document transcrit és encapçalat amb la data: any, mes $i$ dia. S'hi indica si el document és original o còpia, i $s$ hi assenyalen també les publicacions que l'han citat. No hi manca tampoc, com és lògic, la signatura o cota de cada escriptura que es transcriu, aixi com una eregestav breu, però suficient.

La transcripció és correcta, com era de suposar amb el coneixement paleogràfic de l'autor, que se sotmeté a les normes de la Comission Internacionale de Diplomatique.

Entre els documents se n' ofereixen vuit en làmines.

També hi podem trobar una molt completa bibliografia $\mathrm{i}$ un index de noms de persona o de lloc.

Moltes felicitats per la magnifica tasca portada a terme pel P. Altisent.

\section{Frederic Udina i Martorell}

Arnall i Juan, M. Josepa; Pons i Guri, Josep M.

Lescriptura a les terres gironines. Segles $I X$-XVIII. 2 vol. Text i transcripcions Girona: Diputació de Girona, 1993.

Veritable monument paleografico-diplomattic $i$ històric és aquesta obra dels erudits doctors Arnall i Pons i Guri: aquests dos volums editats per la Diputació de Girona constitueixen, gairebé amb luxe, dues manifestacions cientifiques de molt alt nivell, nivell que no es podia ser un altre si tenim en compte qui en són els autors.

Després d'una presentació feta pel president de la Diputació, el Sr. Josep Arnau, li segueix una reivindicació del rector de la Universitat de Girona, el Dr. Josep M. Nadal.

A la justificació, la Dra. Arnall ens hi explica el laboriós esforç que aquest tipus de publicacions comporten, i per aquesta raó són escasses aquestes obres. A més, hi fa referència a la recent obra de la doctora Mateu Ibars (la Collectane paleografica) i rememora el record del doctor Canellas i el seu interès per la publicació d'aquest tipus d'obres. L'autora va començar aquesta obra en la recerca de fonts, però en connectar amb el nostre benvolgut Pons i Guri la tasca li va resul- tar més facil pels grans coneixements que tenia i té aquest arxiver d'Arenys de Mar.

El llibre aplega la documentació més representativa de l'àmbit gironí $\mathrm{i}$ no es tracra solament d'un estudi paleogràfic, ni tan sols diplomàtic, sinó que, com dèiem, també és històric. La selecció de la documentació s'ha fet amb un criteri molt ampli: no solament s'ha tingut en compte que el document o el manuscrit procedeixi o es guardi ja a les terres gironines, sinó que procedeixi d'aquestes. D'altra banda apareix una exhaustiva tipologia documental, i mentre que el primer volum és una mostra ben palesa de l'erudició dels autors, el segon ens ofereix una bella mostra de la riquesa artística $i$ històrica de documents i manuscrits que s'estudien.

Amb molt d'encert els autors expliquen els criteris que han imperat en la selecció i que ha donar lloc a 346 documents, que vol dir el mateix nombre de làmines, des de la molt reculada data de l'any 827 fins al 1799. En aquest primer 
apartat de criteris per a la selecció ja sorprèn la quantitat de notes que hi ha; després es parla de la llengua en la documentació que s'ofereix i hi ha una data molt interessant: el primer document en llengua catalana és de 1330 (làmina 88). Després la doctora Arnall s'entreté amb la qüestió de l'escriptura visigòtica i la seva evolució amb l'adopció de la carolíngia, aixi com més tard del pas de la carolíngia a la gòtica i d'aquesta a la humanística.

No oblidant mai la cura que cal tenir en edicions d'aquest tipus, els autors s'entretenen amb les normes de transcripció, sense deixar de banda el caràcter d'estudi crític que la documentació exigeix; així explica com es presentaren cls documents: identificació del text (núm. d'ordre, indicació del centre (arxiu, biblioteca...), fons al qual pertany, signatura, matèria escriptòria i mides. A continuació hi ha una eregesta» molt adequada precedida de la data (any, mes, dia i lloc, en el seu cas) i bibliografia.

S'explica en un apartat especial la sistematica per als textos llatins i a part per als catalans. I finalment s'explana una terminologia emprada en P'anàlisi paleogràfica, en què apareixen dibuixos amb el perfil de lletres, seguint l'ordre alfabètic.

Encara que la reproducció dels documents apareixen al segon volum, tal com he dit i del qual parlem a continuació, hi ha dotze làmines en color, després del darrer document, el núm. 346; les més destacades són les de l'Evangeliari del segle $\mathrm{XI}$, la Bíblia de Ripoll, del Vaticà, del mateix segle, un fiximenis, etc.
Hi ha més matèria digna d'esmentar: un glossari de mots llatins i catalans i una bibliografia molt extensa. Tanquen el volum primer uns indexs: de centres documentals, de sigles de caràcter general, de llocs dels centres documentals, de eronologia dels documents, de conceptes, d'onomastica $\mathrm{i}$ de toponímia.

No cal pas insistir en la gran cura i riquesa de dades que ens ofereix el primer volum d'questa obra.

El segon ofereix de la mateixa manera que la transcripció $\mathrm{i}$ altres detalls assenyalats, la mateixa preocupació acurada del primer volum. S'encapçala aquest amb un sumari cronològic dels documents, des de la làmina 1, document de l'any 827 , fins a la 346 , del segle XVIII. A continuació comencen les làmines, totes en negre (no en color) amb indicació de la procedència del document, signatura i mides. Són làmines ben impreses i facils de llegir. Per tal de fer més llegibles algunes làmines corresponents a documents molt extensos, hi ha un apèndix amb dotze documents, que permeten una lectura còmoda, que sense haver tingut aquesta cura, hauria estat dificil $i$ gairebé impossible fer-ho amb la reproducció primera.

Per acabar, una felicitació ben merescuda, cordial $i$ afectuosa per als autors d'aquesta magnifica obra que la Diputació de Girona ha fet possible amb la seva generositat. Potser solament fariem una petita observació: a la nota diplomàtica de cada document s'hi podia haver indicat si es tractava d'un original o d'una còpia.

Frederic Udina i Martorell 